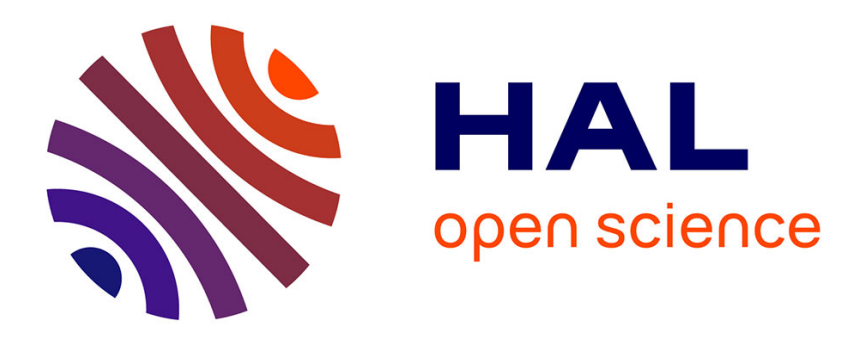

\title{
Measuring fuel poverty in France: Which households are the most fuel vulnerable?
}

Bérangère Legendre, Olivia Ricci

\section{To cite this version:}

Bérangère Legendre, Olivia Ricci. Measuring fuel poverty in France: Which households are the most fuel vulnerable?. Energy Economics, 2015, 49, pp.620-628. 10.1016/j.eneco.2015.01.022 . hal01283999

\section{HAL Id: hal-01283999 \\ https://hal.univ-grenoble-alpes.fr/hal-01283999}

Submitted on 7 Mar 2016

HAL is a multi-disciplinary open access archive for the deposit and dissemination of scientific research documents, whether they are published or not. The documents may come from teaching and research institutions in France or abroad, or from public or private research centers.
L'archive ouverte pluridisciplinaire HAL, est destinée au dépôt et à la diffusion de documents scientifiques de niveau recherche, publiés ou non, émanant des établissements d'enseignement et de recherche français ou étrangers, des laboratoires publics ou privés. 


\title{
Measuring fuel poverty in France: which households are the most vulnerable?
}

\author{
Bérangère Legendre $^{a}$ and Olivia Ricci ${ }^{b}$
}

\author{
${ }^{a}$ Université de Savoie - IREGE 4, chemin de Bellevue, BP 80439, 74944 Annecy-le- \\ Vieux, France ; berangere.legendre@univ-savoie.fr \\ ${ }^{\mathrm{b}}$ Université de la Réunion - CEMOI, 15 avenue René Cassin, BP 7151, 97715 St-Denis, \\ La Réunion ; olivia.ricci@univ-reunion.fr; Corresponding author : 0692415044 - 0262938451
}

\begin{abstract}
Fuel poverty is a growing concern in France. Following the hike in energy prices that started in 2004, the problem of energy affordability for low-income households entered the political debate with the "Grenelle de l'environnement" in 2007. According to the standard UK definition (10\% ratio) 3.8 million households were subject to fuel poverty in France in 2006. We question the way fuel poverty is currently measured and compare the impact of alternative measurement approaches on the extent and composition of fuel poverty in France. Then, we identify and characterize vulnerable households that are not ordinarily poor, but can be pushed into poverty because of their fuel bills. A logit, a clog log and a mixed effect logit model are used to analyze which factors influence the probability of vulnerable households to fall into poverty. The study indicates that the proportion of fuel poor people and their characteristics differ significantly depending on the fuel poverty measure chosen. The econometric results show that the probability of falling into poverty is higher for those who are retired living alone, rent their home, use an individual boiler for heating, cook with butane or propane and have poor roof insulation. Current French fuel poverty reduction policies appear to be inappropriate given our conclusions.
\end{abstract}

Keywords: Fuel poverty, vulnerable households, poverty indicators, clog log model 


\section{Introduction}

Fuel poverty in developed countries is a serious problem from three main perspectives: poverty and reducing it; health and well-being; decreasing carbon emissions and saving energy (Hills, 2011). These issues are quite different from those raised in developing countries, where energy poverty addresses especially the question of the access to modern energy sources (Nussbaumer, et al. 2011). The existing literature discussed extensively the link between energy poverty and global development issues: energy is central to eradicate poverty in the developing world, and improving human welfare (UNDP, 2000; IAEA, 2005, Pachauri et al., 2004; Pachauri and Spreng, 2004, 2011). Fuel poverty and energy poverty must consequently be distinguished ( $\mathrm{Li}$ et al, 2013). We focus in this article on fuel poverty. Fuel poverty was first defined as the difficulty for households to afford adequate warmth in their home (Lewis, 1982). Boardman (1991) showed that fuel poverty occurs when a household needs to spend more than $10 \%$ of its income on fuel costs in their home to maintain satisfactory indoor temperature. In France, Devalière et al (2011) showed that 3.5 million of households suffered from cold in their home in 2006 and 3.8 million spent more than $10 \%$ of their income to pay their energy bill.

Fuel poverty in developed countries has several causes which are almost always combined: low-energy efficient housing, rising fuel prices, and low incomes (EPEE, 2006; IEA, 2011; Rappel, 2011; Palmer et al., 2008). There is a considerable overlap between fuel-poor households and those with low incomes. Using a widely adopted income poverty measure (60\% median equivalised income threshold), Palmer et al. (2008) showed that nearly three quarters of the fuel poor in England in 2005 were also income poor. From a definition point of view, many institutions and countries showed that monetary and fuel poverty were inextricably linked, representing both an aspect of multidimensional poverty. For instance, the Energy Act 2010, which introduces the concept of reducing both the extent and the depth of fuel poverty in the UK, defines fuel poverty as a dual issue, involving households on low incomes faced with unreasonable fuel costs. In France, the current fuel poverty policy was created in 2010 during the French environment roundtables called "Grenelle de l'environnement", under the law "Grenelle 2" $\mathrm{n}^{\circ}$ 2010-788 ${ }^{1}$. The law defines the concept of fuel poverty. A person suffering from fuel poverty is "anyone who encounters, in their home, particular difficulties in obtaining the energy required to meet their basic energy needs due to insufficient resources or housing conditions". The law has since been complemented by a measurement approach inspired by the United Kingdom ${ }^{2}$. According to the 2001 UK Fuel Poverty Strategy, a household is considered to be in fuel poverty if it needs to spend more than $10 \%$ of its total income before housing costs on fuel to heat its home to an acceptable level.

There are numerous criticisms of the current $10 \%$ objective measure, the main one being that it fails to capture all of the main drivers of fuel poverty (Hills, 2011). In fact, this ratio can capture households with high energy costs, but not all of these households are on low incomes. This is why significant numbers of households with relatively high incomes have been found to be fuel poor even though they should be able to absorb the cost of higher bills (Hills, 2011; Moore, 2012). Other households can even be pushed into poverty because of energy costs without reaching the $10 \%$ ratio.

Therefore, much debate focuses on how to measure fuel poverty given the potential difficulties in identifying one single indicator that will satisfactorily capture all of the issues. In order to target low-income households, fuel poverty can be studied from a perspective of poverty concern in general, using the after fuel cost poverty approach (Hills, 2011). This consists in measuring residual income (i.e. after housing and fuel costs) and comparing it to an

\footnotetext{
${ }^{1}$ Loi $\mathrm{n}^{\circ} 2010-788$ du 12 juillet 2010 portant sur l'engagement national pour l'environnement.

${ }^{2}$ This complementary fuel poverty measure is not included in the law.
} 
income standard such as the poverty line (threshold of $60 \%$ of the national equivalised income level). There is a clear interest in establishing whether some households may be exposed to poverty because of high fuel costs. Hills (2011) has also proposed an alternative measurement framework focusing directly on the overlap of high costs and low income (the Low IncomeHigh Costs indicator).

Little empirical research has been undertaken on fuel poverty in France. The European Fuel Poverty and Energy Efficiency Project (EPEE project) in 2006 proposed a descriptive approach of fuel poverty in France using three subjective criteria (capacity to pay to keep one's home warm, the existence of dampness, leaks, mould in the accommodation, and the arrears on electricity, gas and water bills). Depending on the subjective criteria the composition of the fuel Poor differed significantly. Therefore, this approach failed to precisely characterize fuel poverty. Although the redistributive architecture and the welfare State are known to reduce the monetary poverty quite efficiently in France (Cazenave et al., 2011). However policy makers face some difficulties to target efficiently the fuel Poor and to decrease this form of poverty. Policies attempting to reduce fuel poverty in France have been designed using only the restrictive $10 \%$ ratio, which is subject to criticisms as we have seen.

This article examines the multiple aspects of fuel poverty in France according to different existing measurement approaches: the " $10 \%$ ratio approach" , "the after fuel cost poverty approach", and the "Hills approach" (Low Income High Costs indicator) and proposes a complementary approach. Using those three measurement approaches do not allow identifying households that are at risk of falling below the poverty line specifically because of high fuel costs. This study represents the first attempt to define what fuel vulnerability is by studying households on the edge of poverty. Households can be classified as vulnerable in the sense that they are a priori non-poor before the fuel bills but a marginal increase in energy prices is enough to make them slip below the threshold ${ }^{3}$. Such an approach allows us to identify the impact of high fuel costs on the margins of poverty. A specific policy targeting such households could be implemented to help them shift above the threshold and therefore reduce the extent of fuel poverty in France.

This paper attempts to provide some answers to the following question: what are key factor of fuel vulnerability and how to protect vulnerable individual from falling below the poverty line? But answering this question necessarily requires understanding why the existing measurement approaches might be inadequate.

After giving an overview of the extent of fuel poverty and the composition of the fuel poor in France using the existing measurement approaches, we conduct an income-based analysis in order to quantify and identify vulnerable households. We use the Foster, Greer and Thorbecke (FGT) (1984) indicator to calculate the incidence, depth and severity of poverty and then estimate logit and complementary log-log regression models to characterize vulnerable households that are pushed into poverty because of fuel costs. Using a less limited methodology, namely a mixed effect logistic regression model, we next assess the robustness of the econometric estimates. The database used for this study is the French housing survey "enquête logement 2006" (Insee, 2006). It is a detailed and representative survey that includes data on income and information on housing conditions.

This paper is organized as follows: Section 1 presents a literature review of the different fuel poverty measures. Section 2 describes the methodology used and the data. Section 3 relates the statistics on the impact of the three objective fuel poverty approaches on the extent

\footnotetext{
${ }^{3}$ In this study the notion of "vulnerability" does not encompass a range of wellbeing and social issues, such as older people, the long-term sick and disabled people, etc. Vulnerable households are those for which the energy cost is the triggering poverty factor.
} 
and composition of the fuel poor in France. Section 4 presents the empirical analysis. Section 5 shows the results and their robustness, and sets out some policy implications.

\section{Fuel poverty measures in the literature}

While there is a widespread agreement on the concept of fuel poverty, its measurement differs markedly, leading to significant implications in terms of the extent of fuel poverty and fuel-poor households characteristics.

The most common objective measure of fuel poverty, called in this paper the "10\% ratio approach", is the $10 \%$ threshold, which means that households with a ratio between expenses and income in excess of 0.1 are classified as fuel poor.

$$
\text { Fuel poverty }=\frac{\text { Required fuel costs }}{\text { Income }}>10 \%
$$

This indicator uses income before housing costs (BHC) and it is not equivalised (adjusted to household size and composition). The required fuel costs are estimated based on income data and modeled physical data relating to dwelling characteristics and energy efficiency. The advantage of focusing on required, rather than actual, fuel spending is that it takes underconsumption into account (Dubois, 2012; Fahmy, 2011). However, this measure is open to a number of criticisms (for a detailed description of the indicator's weaknesses, see Hills, 2011). Some of these criticisms relate to its intrinsic ratio form and some to the way income is calculated.

Firstly, using a ratio to determine the extent of fuel poverty does not include a cut off for households with high income. Therefore, a significant number of high-income households were found to be fuel poor with this measure (Hills, 2011; Moore, 2012). This is not in line with the definitions exposed in the introduction.

Secondly, income is not adjusted to account for households' different compositions and sizes. Therefore, it overestimates the incomes available to larger households to meet these domestic fuel needs. Empirical analyses suggest that income equivalence has a substantial effect on the social and demographic composition of the fuel poor (Fahmy, 2011).

Thirdly, experts argue that income should be measured after housing costs (AHC) to give a true picture of a household's disposal income and therefore the affordability of fuel bills, given that housing costs are usually met before other types of consumption (Hills, 2011; Moore, 2012). Housing costs are highly geographically variable, therefore, estimating incomes on a before housing cost (BHC) basis can produce misleading estimates of the extent and spatial distribution of fuel poverty.

In order to capture households on low income, we can use a broader measure of fuel poverty using traditional indicators from income poverty. Eurostat's definition of poverty risk refers to individuals living in households where the equivalised income is below the threshold of $60 \%$ of the national equivalised median income. Under this approach, households whose equivalised income after housing costs (HC) and fuel costs (FC) falls below the threshold are classified as fuel poor. This approach is presented by Hills (2011) and it is called "after fuel cost poverty" approach. This approach successfully identifies households that are in income poverty and whose situation is worsened by fuel costs. However, within this indicator nearly all households with very low income are classified as fuel poor regardless of their fuel requirement. This approach does not properly reflect the distinct nature of fuel poverty but rather gives insights to the broader concept of poverty. 
The Hills's approach (2011) recommends adopting a new indicator of the extent of fuel poverty: the "Low Income-High costs" indicator (LIHC). This indicator captures households that have a combination of low income and relatively high costs by establishing two specific thresholds:

$\checkmark$ The income threshold is the same as for the "after fuel cost poverty approach". It is consistent with official poverty measurements;

$\checkmark$ The energy cost threshold is based on the median required spending of all households.

Therefore, households that are below the conventional $60 \%$ of the median income poverty line and have fuel costs above the median level are classified as fuel poor.

This indicator is consistent with the definition of fuel poverty as it takes into account the level of income as well as the relative weight of the energy spending. However, this approach will not give a precise identification of households that are pushed into poverty because of fuel costs. Moreover, fixing the energy cost threshold to the median is essentially arbitrary.

The literature shows that some individual and households characteristics are associated with difficulties facing the energy costs. Fuel poverty can be measured with objective indicators as we have seen, but some authors also use more subjective criteria. Using the ability to heat the home adequately as fuel poverty criteria, Healy (2003) shows that in Ireland, family and social factors impact the probability of being fuel poor. Living alone and having dependent children is especially associated with financial difficulties and difficulties to heat the home. The EPEE project underlines some similarities across France, United Kingdom, Belgium, Spain and Italy in fuel poverty aggravating factors: being tenants, single people, among them especially pensioners. Pensioners suffer from higher risk to have a low income, which is combined with high energy needs. Housing tenure is an important dynamic of fuel poverty (Whyley and Callender, 1997; Healy, 2003, Boardman, 2010, Devalière, 2011; Hills, 2012) since it gives households different levels of control concerning their home. Owner-occupiers are fully autonomous while tenants are more limited in their choices. However, homeowners also endure significantly higher financial burdens for their home maintenance. Using the rate of energy effort (10\% approach), Devalière calculates that French fuel Poor are in majority homeowners, which contradicts the findings of the EPEE project. This contradiction comes from the differences of the approaches: the EPEE project considers a subjective indicator: the declared ability to pay to keep home adequately warm, while Devalière uses $10 \%$ objective approach. Devalière (2009) found also that pensioners exhibit high levels of fuel poverty. A third of them declare suffering from a thermal discomfort. Heating is the most important item of energy expenditure. It accounts for about $50 \%$ of the accommodation energy bill in France (ADEME, 2005). The age of a property has also a significant influence on energy costs (Hills, 2012). Using a subjective measure of fuel poverty, Devalière (2011) showed that French households who reported suffering from cold lived more often in houses built before the first thermal regulation in 1974. In France, on 25.65 million of households, 1.59 million declared having difficulties in paying to keep home adequately warm, 3.13 million declared leaking roof, damp walls/floors/foundation, or rot in window frames or floor, and 1.64 had arrears on utility bills (EPEE, 2006).

Current studies on fuel poverty use different definition and measures leading to contrasting results in terms of the composition of the fuel poor. The lack of a precise indicator does not allow designing efficient policies, which raises two main issues: a measurement problem, combining with a targeting problem ex ante and a policy evaluation issue ex post.

\section{Methodology and data}

In a first place, we propose measuring the extent and composition of fuel poverty in France using the three objective approaches described above ( "10\% ratio approach" , "after fuel 
cost poverty approach" and "Hills' approach" ). However, as household composition and housing costs were a main criticism of the traditional $10 \%$ ratio measure, we will adjust gross income in the three approaches to take these two aspects into account. Moreover, it is easier to compare the indicators on the same basis. In all three approaches, gross income takes households' size and composition into account and is calculated after housing costs.

To calculate the $10 \%$ ratio, we use actual spending rather than expected ones, as existing surveys do not provide indication on theoretical energy spending ${ }^{4}$.

We assign to each member of the household an equivalent income value, calculated using the OECD equivalence scale. Economies of scale in housing and the consumption of goods and services are allowed for controlling household composition. Some existing literature underlines the potential asymmetry in the management of, and access to, household resources (Browning, Bourguignon, Chiappori and Lechêne, 1994; Roy, 2005; Belleau and Proulx, 2010, 2011). Nevertheless, assuming that most households share and manage their income in a fair manner, we deflate the household resources by the number of consumption units in the household. We assign a value of 1 to the first household member, 0.5 to each additional adult member and 0.3 to each child under 14 years old. This method has the advantage of showing households' standards of living more precisely.

It is often used in income poverty measurements to deduct housing expenditure (mortgage payments or rents) from income and show the share of households under the poverty line (Hills, 2011, Moore, 2012). In fact, the amount households must spend is only ever an imperfect measure of the standard of living they can achieve, but for many things the same cash amount can translate into similar items in a shopping basket, meeting their needs in similar ways. The greatest exception to this is housing, because of the huge variations in rents and house prices across the country and the difficulty people would face in moving. Under the after fuel cost poverty approach, we have calculated the extent of poverty with the poverty rate (headcount), but it is also possible to study the depth and severity of poverty using the poverty gap and square poverty gap indicator (Foster, Greer and Thorbecke, 1984) (see table 1). The FGT indicator has the advantage to provide three dimensions of poverty and eventually to complement the after fuel cost poverty approach. The poverty gap shows how far below the poverty line people are affected. This is an interesting indicator for ascertaining whether the situation improves, for instance, when the poor move closer to the poverty line, even when only a few of them cross it. The square poverty gap takes into account not only the distance separating the poor from the poverty line (the poverty gap), but also inequality among the poor. A higher burden is placed on those households furthest away from the poverty line.

The headcount which is similar to the after fuel cost approach, the poverty gap and the squared poverty gap are the three measures that can be obtained using the general formula of the Foster, Greer and Thorbecke indicator (FGT):

$$
F G T_{\alpha}=\frac{1}{n} \sum_{i=1}^{q}\left(\frac{z-y_{i}}{z}\right)^{\alpha}
$$

$n$ is the population size, $q$ is the number of poor (those with incomes at or below the poverty line $z), y_{i}$ are individual incomes and $\alpha$ is a sensitivity parameter.

When $\alpha$ has a value of zero, we obtain the headcount, when $\alpha$ is equal to one, we obtain the poverty gap and when $\alpha$ is equal to two, we obtain the squared poverty gap. In this after fuel cost poverty approach, three levels of income can be considered to capture the effect on each spending on the exposure to fuel poverty: gross income, gross income after housing costs, gross income after housing costs and fuel costs.

\footnotetext{
${ }^{4}$ The consequence is that energy expenditures might be under-estimated compared to those which could provide an adequate level of thermal comfort. This limitation will be treated in further works with appropriate econometric specifications.
} 
The definition of fuel poverty indicators raises serious questions. First, pursuing a fuel poverty reduction policy requires precisely defining who the fuel-poor are. Which population is the most vulnerable? It is vital to identify these inhabitants ex ante in order to conduct an efficient policy. Secondly, policy makers need relevant indicators to measure the efficiency of their policy ex post. Therefore, reliable tools are needed. Depending on the fuel poverty indicators chosen, the targeted population will not be the same, and the results of the policy will change. Households and individuals identified as fuel poor using the three approaches described above can suffer from different forms of precariousness, none of them being specifically and uniquely triggered by the energy bills.

For this reason we propose to target the groups in society that are most vulnerable to energy costs and at risk of falling into fuel poverty because of this burden. Our starting point is the after fuel cost poverty approach. As we have seen, the main weakness of this approach is that it does not allow us to specifically study the nature of fuel poverty because these households are concerned with much broader poverty issues and energy bills only worsen their situation. To evaluate the vulnerability aspect of this problem, we chose a sample of households that were not poverty exposed before the fuel bill.

Targeting households that are pushed into poverty because of their fuel bills is important for understanding which type of household should be prioritized for support through fuel poverty reduction policies. The aim of the following econometric analysis is to develop a model of the most influential demographic, socioeconomic and housing characteristics affecting the likelihood of a household falling into fuel poverty, for households that are not $a$ priori poor.

We have a choice of sources for income data as well as housing and energy expenditure. The only survey in which income data is available in combination with information on housing conditions and expenditure is the French housing survey "Enquête Logement 2006" conducted by the French National Institute of Statistics and Economic Studies (Insee, 2006). In 2006, the survey sample covered over 70,000 dwellings (about 60,000 in Metropolitan France and 10,000 in the overseas departments) and a total of 43,000 households responded to the survey. Data were collected using computer-assisted personal interviews. The survey includes more than 1000 variables related to the characteristics of the housing stock, the quality of the dwellings and the expenditure associated with housing.

Housing costs in the database include rents and mortgage payments minus housing allowance. For the after fuel cost poverty and Hills approaches, fuel costs are subtracted from income. In the French Housing Survey, fuel costs comprise water, electricity and other fuel expenses.

\section{Statistics on the extent and composition of fuel poverty}

We study the extent and composition of fuel poverty in France using the "10\% ratio approach" , "the after fuel cost poverty approach" and the "Hills" approach" .

Figure 1 shows the extent of fuel poverty in France using the different measures.

Figure 1: The extent of fuel poverty in France using different approaches 


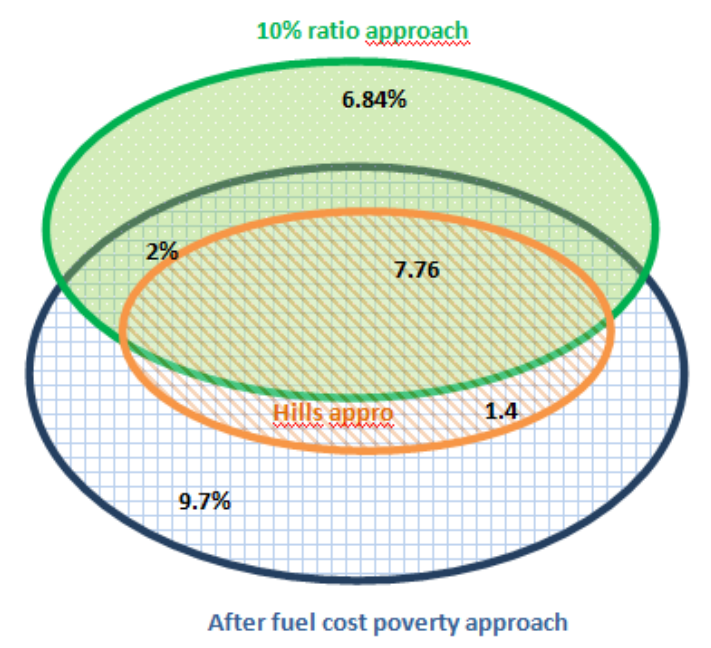

Source: Enquête Logement, authors' calculations , $\mathrm{N}=40136$

Key to read: $6.84 \%+7.76 \%+2 \%$ are fuel poor according to the $10 \%$ approach $7.76 \%$ are fuel poor according to the three definitions, while $2 \%$ are fuel poor according to the $10 \%$ approach and the after fuel cost approach.

Fuel poverty rates vary notably for the three measures. $16.6 \%{ }^{5}$ of the French population is considered as fuel poor according to the $10 \%$ ratio approach; $20.9 \%$ according to the after fuel cost poverty approach and $9.2 \%$ according to the Hills approach. Within the $16.6 \%$ of fuel poor under the $10 \%$ ratio approach, $6.84 \%$ are not exposed to poverty after housing and fuel costs under the after fuel cost poverty approach. Also, of the households that are found to be fuel poor under the after fuel cost poverty approach, $11.14 \%$ do not spend more than $10 \%$ of their income on energy expenses.

The above figure illustrates that the $10 \%$ ratio approach includes households that do not necessarily have a low income and it also demonstrates that the rate of $10 \%$ is arbitrary because a household can still be poor with lower energy expenses. We found that among the households in the last decile group (10\% of the population with the highest income), $1.15 \%$ were fuel poor under the $10 \%$ ratio approach. Moreover, households' annual gross income is on average $€ 11681^{6}$ for those who are poor according to the after fuel cost poverty approach, $€ 11,980$ for those who are poor according to the Hills approach and $€ 14,128$ for those who are poor according to the less restrictive $10 \%$ ratio approach.

Also, according to the after fuel cost approach only $43 \%$ of the poor spend more than $10 \%$ of their gross income on paying the energy bill. For them, the energy bill represents almost $22 \%$ of gross income. For the $57 \%$ who do not reach the $10 \%$ ratio, energy expenses represent about $6 \%$ of gross income.

The Hills approach brings out both approaches as the thresholds used ensure that only households on very low incomes with very high fuel costs are considered as fuel poor.

\footnotetext{
${ }^{5} 6,84 \%+7,76 \%+2 \%$

${ }^{6}$ Household annual gross income here is not deflated by the number of consumption units in the households
} 
Table 1: Poverty rate, gap and severity

\begin{tabular}{|c|c|c|c|c|c|c|c|}
\hline & $\begin{array}{l}\text { Povert } \\
\text { y rate }\end{array}$ & $\begin{array}{r}\text { Pov } \\
\text { erty gap }\end{array}$ & $\begin{array}{l}\text { Sev } \\
\text { erity }\end{array}$ & $\begin{array}{l}\text { Poverty } \\
\text { line (euros } \\
\text { per CU) }\end{array}$ & $\begin{array}{c}\text { Mean } \\
\text { income } \\
\text { (euros per } \\
\text { CU) }\end{array}$ & $\begin{array}{l}\text { Mean } \\
\text { income under } \\
\text { the poverty line } \\
\text { (euros per CU) }\end{array}$ & $\mathrm{N}$ \\
\hline $\begin{array}{c}\text { Gross } \\
\text { Income }\end{array}$ & $17.59 \%$ & 0.05028 & 0.02316 & 9869.4 & 19631 & 7048.28 & \\
\hline $\begin{array}{c}\text { Gross } \\
\text { Income - } \\
\text { housing costs }\end{array}$ & $18.94 \%$ & 0.06098 & 0.03083 & 8700.6 & 17607.53 & 5899.87 & 40136 \\
\hline $\begin{array}{c}\text { Gross } \\
\text { Income - } \\
\text { (housing costs } \\
\text { + energy cost) }\end{array}$ & $20.90 \%$ & 0.07273 & 0.03994 & 8215.14 & 16685 & 5356.58 & \\
\hline
\end{tabular}

$17.59 \%$ of the population is exposed to poverty before redistribution ${ }^{7}$. After housing and energy bills, almost $21 \%$ of the population is exposed. This increase in poverty is associated with more inequalities: mean gross income of poor households represents $35.9 \%$ of the mean gross income within the population ${ }^{8}$, but mean income after housing and energy costs represents $32.1 \%$ of the average. We can deduce that those expenditures weigh more heavily on poorer households.

The composition of fuel-poor households across different socio-economic and dwelling characteristics differ depending on the approach retained (appendix 1).

When looking at the professional categories of the heads of household, we note some differences between the approaches. Under the after fuel cost poverty approach a large proportion of the poor are active ( $40 \%$ of the poor are employees or blue collar workers), whereas, in the two other approaches they are mainly inactive. Pensioners are more frequently energy poor. However, it appears that pensioners do not combine necessarily low incomes ${ }^{9}$ with high energy expenses, but are probably faced with significant fuel costs compared to their standard of living. Under the $10 \%$ ratio and the Hills approaches respectively $54 \%$ and $45 \%$ of the poor are pensioners, while under the after fuel cost poverty approach, which mainly targets low incomes, only 30\% are pensioners. On average, pensioners represent $33 \%$ of the French population. They are consequently over-represented in the fuel poor population (according to the $10 \%$ and the Hill approaches).

We observe that the average head of household is 57 years old according to the Hills measure of fuel poverty, 60 years old according to the $10 \%$ ratio approach, but only 50 years old under the after fuel cost poverty approach. This also explains why a greater proportion of individuals are widowed in the fuel-poor population targeted by the Hills and $10 \%$ approaches (26\% and $29 \%$ against $15 \%$ with the fuel poverty' s broader approach). When focusing on household composition more than marital status, we observe that the poor are mainly people living alone. The poor household composition seems to be more or less the same under the three approaches.

The fuel poor are mainly homeowners for the $10 \%$ ratio approach and the Hills approach (respectively $66 \%$ and $53 \%$ ) while under the after fuel cost poverty approach $63 \%$ of the fuel poor are tenants. This last approach includes a larger share of the population that was already

\footnotetext{
${ }^{7}$ According to the French Statistical Office (INSEE), the poverty rate, calculated after redistribution attained $13.1 \%$ in 2006 . We calculate in this paper the poverty headcount using the gross income per consumption unit while official statistics provide poverty rate the net income per unit of consumption (after redistribution).

$87048,28 / 19631=0,359$

${ }^{9}$ In France, retirees enjoy in average a standard of living close to that of workers.
} 
income poor before housing and energy costs. It is therefore logical to find more tenants when using this approach. This is in line with literature on poverty in general, where the results show that the poorest are usually tenants (Insee, 2013). As the 10\% ratio approach does not cut off low-income households, it is intuitive to find more homeowners than in the two other approaches. Moreover, as this approach includes a large portion of pensioners, it is consistent with the housing occupation status.

We find that $76 \%$ and $71 \%$ of the poor live in detached houses under the $10 \%$ ratio and the Hills approach respectively, while under the after fuel cost poverty approach $54 \%$ of the poor live in an apartment. The fuel poor under the $10 \%$ and Hills approaches are more likely to live in a detached house than the average population (on average, 58\% of the population live in a detached house), while with the after fuel cost poor are more likely to live in an apartment than the average population (41\%).

We observe that the majority of the fuel poor under the three approaches use an individual boiler as the main heating system in their house: $65 \%$ of the poor under the $10 \%$ ratio, $60 \%$ under the Hills approach, and that the number is less significant under the after fuel cost poverty approach (38\%). Those living in poverty under the three approaches also more frequently use butane and propane for cooking than the average population (about $40 \%$ against only $24 \%$ on average). In contrast, the average population more frequently uses electricity to cook (27\%) than the fuel poor under all three approaches. Among the after fuel cost poor, only $12 \%$ use electricity, compared to $16 \%$ among the fuel poor with both of the other approaches.

In the French housing survey, one subjective indicator relates to why respondents feel cold in their home. The main reasons for feeling cold given by the fuel poor relate to housing quality. Of the three approaches, above $40 \%$ of the fuel poor declared that they suffered from cold due to poor insulation, and more than $30 \%$ due to insufficient heating installation. Moreover, one out of three households limit their heating consumption due to its cost. In the average population, $41 \%$ said they suffered from cold due to poor insulation, and $19 \%$ due to equipment breakdowns, compared to only around $13 \%$ for the poor population (under the three approaches). Statistics on feeling cold as a result of under-consumption of heating is particularly informative: while on average $21 \%$ of respondents declared that they suffered from the cold because of under-consumption, $36 \%$ of the fuel poor gave this reason under the $10 \%$ and Hill approaches, and $29 \%$ among the after fuel cost poor. In other words, the fuel poor are constrained in their energy consumption, which might have a strong impact on their well-being.

Depending on the characteristics observed, the three indicators do not depict the same situation. It shows why leading and evaluating economic policies to reduce fuel poverty might be particularly problematic. Targeting fuel vulnerability has the virtue to identify clearly individuals for whom energy bills trigger the difficulties. Providing financial support to those populations would suppress the energy as poverty factor.

\section{Empirical analysis}

To target fuel vulnerable households we have to study households who were not poverty exposed before the fuel bills using the after fuel cost poverty approach. 26531 observations remain in our sample. Ultimately, households that became poor specifically and uniquely because of their fuel expenses represent $2.76 \%$ of our observations (See table in appendix B).

\subsection{Logit and Complementary log-log models}


Logistic and complementary log-log regression models have been constructed to examine the factors that influence the probability of falling into fuel poverty in France.

Using logistics allows us to verify whether the patterns commonly seen across fuel poverty are actually associated with single characteristics or a combination of several characteristics. The advantage of the logit and complementary log log models is the direct relationship between the coefficients and the hazard ratios, which provide pieces of information that are easy to interpret. By exponentiating the coefficients, we can determine the effect of each variable on the odds of a fuel-poor individual, compared to individuals possessing the baseline set of reference characteristics. The odd ratio is the ratio between the probability of "success" and the probability of "failure" 10 .

Let $Y_{i}$ denote a random variable representing a binary response. We define $Y_{i}$ equal to 1 if the individual is pushed into poverty because of the energy cost, 0 otherwise. The probability of being fuel poor $\pi_{i}$ can be written as $\pi_{i}=P\left(Y_{i}=1\right)=P\left(Y_{i}^{*}>\theta\right)$ with $Y_{i}^{*}$ the latent response. The outcome depends on explanatory variables, so we estimate the following model:

$$
Y_{i}^{*}=x \beta+\varepsilon
$$

Where $x$ is the vector of covariates and $\varepsilon$ the error term. We assume first that $\varepsilon$. follows a standard logistic distribution and estimate a logit regression model.

However, the positive outcome is quite rare in our sample (2.76\% of 1). Therefore, we use a complementary log-log analysis as an alternative to the logit model (Powers and Xie, 2000) to check the robustness of our results. The complementary log-log model is derived from the hypothesis that the error distribution (or distribution of $Y_{i}^{*}$ ) follows a log Weibull distribution. Unlike the logit analysis, the transformation is not symmetrical around 0: it is skewed to the right and therefore used when a positive outcome is rare ${ }^{11}$.

\subsection{Variables}

The explanatory variables have been selected on the basis of existing literature on fuel poverty. First, we introduce socio-demographic and socio-economic variables. Literature shows that some households are more poverty exposed than others. Thus, we introduce variables that characterize housing conditions to be those often associated with difficulties in heating the home adequately and thermally insulating walls and roofs, etc. We select the variables in order to avoid any multicollinearity that might occur when some explanatory variables are highly correlated. Some variables, like for example "living in a detached house" and an "individual boiler" would provide redundant information.

Rather than marital status, we focus on household composition. We assume that compared to couples, those living without a partner are more likely to be exposed to fuel poverty. Moreover, being a pensioner might also be linked with financial hardships: so we consider work status. This piece of information is combined with the household composition.

Table 1 shows that households comprising retired and single people are far more likely to be fuel poor than other household types. $6.93 \%$ of pensioners living alone are below the poverty line. People living alone also on average face a deeper poverty than couples and they suffer from a more severe poverty than other subsamples. This statistic ties in with observations made in the previous section whereby a large proportion of the poor were living alone under the three approaches.

\footnotetext{
${ }^{10}$ Consequently, if the odd ratio is greater than 1, it expresses that there is a greater likelihood of success (dependant variable $=1$ ) than one of failure (dependant variable $=0$ ).

${ }^{11}$ In complementary $\log -\log$ models, $\exp (\beta)$ represents a hazard ratio, or relative risk, rather than odds ratio. However, hazard ratios are equivalent to odd ratios if $p$, the probability of success is small, which the case in our analysis.
} 
Educational attainment is, in general, a good indicator of household income and social class. $6.96 \%$ of people with no diploma experience fuel poverty while this proportion is less than $1 \%$ among those with an intermediate or a high educational level. The poverty gap and severity are also greater for individuals with no diploma.

Descriptive statistics on our sample do not show large differences in poverty exposure between owner-occupiers and tenants, of whom respectively $2.84 \%$ and $2.62 \%$ are exposed, while the average poverty rate is $2.76 \%$ in the sample. However, housing tenure is a key factor of our analysis as we observed previously that depending on the fuel poverty criteria chosen, result can differ significantly. Only the $10 \%$ and the Hills's approaches report that homeowners are more frequently fuel poor. But can we consider that among those who are not fuel poverty exposed before the energy bill, homeowners are more vulnerable?

Many characteristics of the housing impact the exposure to fuel poverty: the location and the age of homes, the heating system, the energy used for cooking, the existence of doubleglazed windows, or the quality of insulation.

The climate zone in which the accommodation is located seems to have a strong influence on fuel poverty as it determines the temperature of homes, although this variable is rarely reported in literature. For example, in northern areas of France the poverty rate reaches 3.33\%, which is higher than in the rest of the country.

The heating system and the type of energy used for the cooking affect the amount of the energy bill: collective energy sources like mains gas seem less expensive for households, while people using butane and propane bottles, whether combined with electricity or not, are more frequently poor.

\section{Results and policy recommendations}

\subsection{Econometric results}

Our models match the data correctly and the predictive power of the logit and complementary log log model is good (see table of results in appendix). Given the rare positive outcome, the latter will be preferred to provide analysis.

The results (See Table 1, and appendix C ) suggest that some household types are exposed to a higher fuel poverty risk. They show that none of the existing definitions should be preferred to the other to characterize vulnerability to fuel poverty. Some results confirm statistics provided by the $10 \%$ ratio and the Hills' approach, other underline on the contrary the relevance of the after fuel cost poverty approach.

These results prove that the vulnerability to energy expenses is specific and different from the picture depicted by current approaches. Key factors to achieve a better and more precise design of economic policies are presented below.

We first analyse the impact of conventional socio-economic variables on fuel vulnerability, without introducing housing characteristics (Partial results are displayed in appendix C). As far as standard characteristics are concerned, the estimates yield significant and expected results.

Then we gradually add to the standard explanatory variables specific variables characterizing the housing. These variables capture key factors that affect energy spending and consequently the exposure to fuel vulnerability. Estimates on control variables are barely affected by the introduction of these housing characteristics. It allows us to be confident that problems of collinearity do not bias our results.

Living with a partner avoid being vulnerable while living alone makes individuals more vulnerable. The hazard ratio calculated after the complementary log log model is particularly 
low for active couples, at $0.251^{12}$, while it exceeds 1 for a retiree living alone $(1,518)$. The marginal effect (See appendix C) reaches $2.66 \%$ for a pensioner living alone. This result is consistent with both the Hills's and the 10\% approaches which record an overrepresentation of the pensioners among fuel Poor. Although French retirees enjoy an average standard of living similar to that of workers, they might be more frequently at the margins of poverty. Living with a partner allows benefiting from economies of scale. Once individuals may find themselves alone, they live, and support related costs, in too big homes.

The more dependent children there are in a household, the higher the likelihood of fuel poverty. Single parent families, widows and widowers are consequently a high risk population. The marginal effect for a family composed of two active adults and two children remains below $1 \%(0.68 \%)^{13}$, but reaches $2.21 \%$ among tenant single parent families with one child. Being a homeowner and highly educated is associated with a lower exposure to fuel vulnerability. Their hazard ratios reach respectively 0.554 and 0.408 . On the contrary, a low level of education increases exposure to fuel poverty. Homeownership seems to be a key factor to avoid shifting below the poverty line especially because of the energy bill. Let us recall that Poor individuals before the energy expenses have been dropped of our sample. Consequently, those for whom fuel expenditures trigger the poverty are in average more frequently tenant than they are homeowner, which contradicts both the Hills's and the $10 \%$ approaches but is in line with the after fuel cost poverty one. This result suggests that fuel vulnerability arises more from a rented accommodation with poor energy efficiency than from the financial burdens for the home maintenance. This is confirmed by the significant and positive coefficient of the variable "living area / Consumption unities (m2)" .

A high level of education might correspond to increased awareness regarding home insulation and/or energy efficiency. Marginal effects calculated within a household whose risk is limited illustrate this result: i.e. $0.62 \%$ for a family ( 2 active adults and 2 children) whose head has been educated to the reference educational level. It reaches $1.68 \%$ in the absence of a diploma and $0.25 \%$ for a high educational level.

Our results show clearly that the type of heating system and the energy used for cooking are key factors to explain fuel poverty. An individual boiler is associated with a high probability of being fuel poor, while collective boilers and district heating systems seem to protect more against fuel poverty. This result is in accordance with the Hills's and the 10\% approaches. Households that heat their home with an individual boiler have the highest odds of being fuel poor (nearly 1.6 times that of households using other types of heating). The marginal effects are significantly higher for those using an individual boiler. For instance, as shown in the appendix, the level is $5.39 \%$ for a homeowner retiree living alone and as much as $3.63 \%$ for a single-parent family. On the contrary, the marginal effect of using a district heating system is only $0.53 \%$ for a single-parent family, and $0.2 \%$ for a family with two children.

Cooking with butane and/or propane, whether mixed with electricity or not, increases the exposure to poverty, whereas using town gas stream (natural gas) and electricity from the grid reduces the exposure.

A poor insulation increases significantly fuel vulnerability: the hazard ratio of a poor insulation of the roof reaches almost 1.29 while having double glazed windows allow to reduce the vulnerability. The hazard ratio is 0.76 .

Finally, the age of the home and the climate zone also significantly impact exposure to fuel poverty. Only housing built after the first thermal regulation in 1974 is associated with a lower fuel poverty exposure. The odds of being fuel poor are lower compared to those living in a building constructed between 1950 and 1974: i.e. 0.836 .

\footnotetext{
${ }^{12}$ Hazard ratios reported here were computed with the estimates including all variables, socio economics and characterizing the housing.

${ }^{13}$ When calculating the marginal effects, the other variables not mentioned are set at their average value or at their reference value.
} 
Econometric results provide a clear picture of housing characteristics increasing the exposure to fuel vulnerability. Some of them were already underlined with previous definitions. Policy options have to be confronted with such results in order to better target population in need, the one who wouldn't be fuel poverty exposed without the energy bill. It appear to be necessary to act on the root causes at the household scale, for example by helping them to install better equipments, or to better insulate their home.

Table 1 Results of the complete estimates: probability to be fuel vulnerable in the population not poor before the energy bill

\begin{tabular}{|c|c|c|c|c|}
\hline & Logit & Odd ratio & $\mathrm{C} \log \log$ & $\begin{array}{l}\text { Hazard } \\
\text { ratio }\end{array}$ \\
\hline $\begin{array}{l}\text { Active couple } \\
\text { Yes }=1 \mathrm{No}=0\end{array}$ & $\begin{array}{c}-1,416 * * * \\
(0,14)\end{array}$ & $0,243 * * *$ & $\begin{array}{c}-1,380 * * * \\
(0,126)\end{array}$ & $0,251 * * *$ \\
\hline $\begin{array}{l}\text { Retired couple } \\
\text { Yes }=1 \mathrm{No}=0\end{array}$ & $\begin{array}{l}-0,332 * \\
(0,168)\end{array}$ & $0,717^{*}$ & $\begin{array}{l}-0,327 * \\
(0,135)\end{array}$ & $0,721^{*}$ \\
\hline $\begin{array}{l}\text { Active living alone } \\
\text { Yes }=1 \mathrm{No}=0\end{array}$ & $\begin{array}{l}-0,208 \\
(0,116)\end{array}$ & 0,812 & $\begin{array}{l}-0,198^{*} \\
(0,110)\end{array}$ & 0,819 \\
\hline $\begin{array}{l}\text { Retired living alone } \\
\text { Yes }=1 \mathrm{No}=0\end{array}$ & $\begin{array}{c}0,444 * * * \\
(0,114)\end{array}$ & $1,558 * * *$ & $\begin{array}{c}0,417 * * * \\
(0,117)\end{array}$ & $1,518 * * *$ \\
\hline $\begin{array}{l}\text { Children in the } \\
\text { household }\end{array}$ & $\begin{array}{c}0,223 * * * \\
(0,0526)\end{array}$ & $1,249 * * *$ & $\begin{array}{c}0,211 * * * \\
(0,037)\end{array}$ & $1,235^{* * * *}$ \\
\hline $\begin{array}{l}\text { Homeowner Yes }=1 \\
\text { No=1 }\end{array}$ & $\begin{array}{c}-0,625 * * * \\
(0,0934)\end{array}$ & $0,535 * * *$ & $\begin{array}{c}-0,590 * * * \\
(0,071)\end{array}$ & $0,554 * * *$ \\
\hline $\begin{array}{l}\text { No diploma } \text { Yes }=1 \\
\text { No }=0\end{array}$ & $\begin{array}{c}1,050 * * * \\
(0,153)\end{array}$ & $2,858 * * *$ & $\begin{array}{c}1,010 * * * \\
(0,156)\end{array}$ & $2,746^{* * *}$ \\
\hline $\begin{array}{c}\text { Low level of } \\
\text { diploma Yes }=1 \text { No=0 }\end{array}$ & $\begin{array}{c}0,420 * * * \\
(0,135)\end{array}$ & $1,522 * * *$ & $\begin{array}{l}0,415 * * \\
(0,159)\end{array}$ & $1,514 * *$ \\
\hline
\end{tabular}

\begin{tabular}{|c|c|c|c|c|}
\hline $\begin{array}{l}\text { A level Yes=1 } \\
\text { No=0 }\end{array}$ & Ref. & Ref. & Ref. & Ref. \\
\hline $\begin{array}{r}\text { Intermediate } \\
\text { educational level }\end{array}$ & $\begin{array}{l}-0,382 \\
(0,222)\end{array}$ & 0,682 & $\begin{array}{l}-0,372 \\
(0,232)\end{array}$ & 0,688 \\
\hline Master's degree & $\begin{array}{c}-0,910 * * * \\
(0,240)\end{array}$ & $0,402 * * *$ & $\begin{array}{c}-0,896^{* * *} \\
(0,211)\end{array}$ & $0,408 * * *$ \\
\hline $\begin{array}{l}\text { Individual boiler } \\
\text { Yes }=1 \mathrm{No}=0\end{array}$ & $\begin{array}{c}0,492 * * * \\
(0,113)\end{array}$ & $1,635^{* * *}$ & $\begin{array}{c}0,477 * * * \\
(0,097)\end{array}$ & $1,612 * * *$ \\
\hline $\begin{array}{l}\text { District heating } \\
\text { Yes }=1 \mathrm{No}=0\end{array}$ & $\begin{array}{c}-1,492 * * \\
(0,448)\end{array}$ & $0,225^{* *}$ & $\begin{array}{c}-1,467 * * \\
(0,572)\end{array}$ & $0,230 * *$ \\
\hline $\begin{array}{l}\text { Collective boiler } \\
\text { Yes }=1 \text { No }=0\end{array}$ & $\begin{array}{c}-1,943 * * * \\
(0,259)\end{array}$ & $0,143 * * *$ & $\begin{array}{c}-1,918 * * * \\
(0,321)\end{array}$ & $0,147 * * *$ \\
\hline $\begin{array}{l}\text { Mixed heating } \\
\text { Yes }=1 \mathrm{No}=0\end{array}$ & $\begin{array}{l}-0,934 * \\
(0,445)\end{array}$ & 0,393 & $\begin{array}{l}-0,913 * \\
(0,424)\end{array}$ & $0,401 *$ \\
\hline $\begin{array}{l}\text { Heating individual } \\
\text { electric convectors } \\
\text { Yes }=1 \mathrm{No}=1\end{array}$ & Ref. & Ref. & Ref. & Ref. \\
\hline $\begin{array}{l}\text { Other type of } \\
\text { heating system }\end{array}$ & $\begin{array}{c}0,112 \\
(0,157)\end{array}$ & 1,119 & $\begin{array}{c}0,109 \\
(0,178)\end{array}$ & 1,115 \\
\hline $\begin{array}{l}\text { Renewable energy } \\
\text { Yes }=1 \mathrm{No}=1\end{array}$ & $\begin{array}{l}-0,560 \\
(0,563)\end{array}$ & 0,571 & $\begin{array}{l}-0,559 \\
(0,595)\end{array}$ & 0,571 \\
\hline Cooking: town gas & 0,13 & 1,138 & 0,137 & 1,147 \\
\hline
\end{tabular}




\begin{tabular}{|c|c|c|c|c|}
\hline streams Yes $=1 \mathrm{No}=1$ & $(0,115)$ & & $(0,135)$ & \\
\hline $\begin{array}{l}\text { Cooking: butane- } \\
\text { propane Yes }=1 \mathrm{No}=1\end{array}$ & $\begin{array}{c}0,808 * * * \\
(0,0959)\end{array}$ & $2,243 * * *$ & $\begin{array}{c}0,785 * * * \\
(0,137)\end{array}$ & $2,193 * * *$ \\
\hline $\begin{array}{l}\text { Cooking: only } \\
\text { electricity Yes }=1 \mathrm{No}=1\end{array}$ & Ref. & Ref. & Ref. & Ref. \\
\hline \multirow{2}{*}{$\begin{array}{l}\text { Cooking:Electricity } \\
\text { and town gas stream } \\
\text { Yes }=1 \mathrm{No}=1\end{array}$} & $-0,535 * *$ & \multirow[b]{2}{*}{$0,585^{* *}$} & $-0,516^{* * *}$ & \multirow[b]{2}{*}{$0,596 * * *$} \\
\hline & $(0,188)$ & & $(0,192)$ & \\
\hline \multirow{2}{*}{$\begin{array}{l}\text { Cooking: Electrivity } \\
\text { and butane/propane } \\
\text { Yes }=1 \mathrm{No}=1\end{array}$} & $0,543 * * *$ & \multirow[b]{2}{*}{$1,721 * * *$} & $0,534 * * *$ & \multirow[b]{2}{*}{$1,706^{* * * *}$} \\
\hline & $(0,124)$ & & $(0,132)$ & \\
\hline Cooking: other & $1,223^{*}$ & \multirow{2}{*}{$3,398^{*}$} & $1,184 * *$ & \multirow{2}{*}{$3,269 * *$} \\
\hline $\mathrm{Yes}=1 \mathrm{No}=0$ & $(0,586)$ & & $(0,473)$ & \\
\hline \multirow{2}{*}{$\begin{array}{l}\text { Housing constructed } \\
\text { before } 1949\end{array}$} & $-0,027$ & \multirow{2}{*}{0,973} & $-0,022$ & \multirow{2}{*}{0,977} \\
\hline & $(0,103)$ & & $(0,096)$ & \\
\hline $\begin{array}{l}\text { Housing constructed } \\
\text { between } 1950 \text { and } 1974\end{array}$ & Ref. & Ref. & Ref. & Ref. \\
\hline \multirow{2}{*}{$\begin{array}{l}\text { Housing constructed } \\
\text { after } 1974\end{array}$} & $-0,186$ & \multirow{2}{*}{0,83} & $-0,178^{*}$ & \multirow[t]{2}{*}{$0,836^{*}$} \\
\hline & $(0,101)$ & & $(0,109)$ & \\
\hline $\begin{array}{l}\text { Climate zone } 1 \\
\text { Yes }=1 \mathrm{No}=0\end{array}$ & Ref. & Ref. & Ref. & Ref. \\
\hline Climate zone 2 & $-0,221 *$ & $0801 *$ & $-0,207^{*}$ & $0813 *$ \\
\hline Yes $=1 \mathrm{No}=0$ & $(0,105)$ & $0,801 "$ & $(0,104)$ & 0,015 \\
\hline Climate zone 3 & $-0,252$ & 0,777 & $-0,236^{*}$ & $0.789 *$ \\
\hline Yes $=1 \mathrm{No}=0$ & $(0,149)$ & $0,1 / 1$ & $(0,126)$ & \\
\hline Climate zone 4 & 0,0027 & 0997 & 0,0029 & 1002 \\
\hline Yes $=1 \mathrm{No}=0$ & $(0,120)$ & 0,991 & $(0,115)$ & 1,002 \\
\hline Double-glazed & $-0,275^{* *}$ & $0,759 * *$ & $-0,258 * * *$ & $0,772 * * *$ \\
\hline window $\mathrm{Yes}=1 \mathrm{No}=0$ & $(0,093)$ & $0, / 39$. & $(0,101)$ & \\
\hline Poor insulation of & $0,272 *$ & $1.313 *$ & $0,254 * *$ & $1288 * *$ \\
\hline the roof Yes $=1 \mathrm{No}=0$ & $(0,111)$ & , & $(0,104)$ & 1,200 \\
\hline Living area / CU & $0,0034 * *$ & $1003 * *$ & $0,0031 * * *$ & $1003 * *$ \\
\hline$(\mathrm{m} 2)$ & $(0,001)$ & $1,00 J$ & $(0,0011)$ & \\
\hline Intercept & $-3,801 * * *$ & $0,022 * * *$ & $-3,813 * * *$ & $0022 * * *$ \\
\hline 1отетере & $(0,233)$ & & $(0,223)$ & \\
\hline $\mathrm{N}$ & & & & \\
\hline LR chi2 & & & & \\
\hline McFadden's R2 & & & & \\
\hline
\end{tabular}

\subsection{Robustness check}

Optimizing energy efficiency and providing households with energy saving equipments will not have the same meaning depending on the quality of build of their housing. For this reason, we propose to take into account possible clusters in our data: we might consider housing level data, with individuals nested in types of housing, approximated by the type of heating system. As explained above, the variables were selected in order to avoid 
multicollinearity in the models. Nevertheless, we can consider that the type heating system is highly representative of the housing category. Having an individual boiler represents for example naturally a high probability to live within a detached house.

Because fixed effects logistic and clog log regressions might ignore the possible sources of non-independence in the data, they could be quite limited. Thus to test the robustness of our results, we estimate a further mixed effect logistic regression (Agresti, 2013).

In addition to usual predictors used in previous models, we introduce a random varying intercept represented by the categorical variable "heating system". The two-level randomintercept model (Powers and Xie, 2000) can be expressed as:

$$
\operatorname{logit}\left(p_{i j}\right)=x_{i j}^{\prime} \beta+u_{i}
$$

Where $p_{i j}$ denotes the probability to be fuel vulnerable for the individual $\mathrm{j}$ in cluster $\mathrm{i}$, in other words, within a housing equipped of heating system of type i. $x_{i j}^{\prime}$ accounts for observed sources of variation in the response, the vector includes the usual variables used in the standard models presented above, except the type of heating system. The error term $u_{i}$ is assumed to be normally distributed with mean 0 and variance $\sigma_{u}^{2}$, and is independent from $x$. To express the random varying intercept model with more clarity, we can rewrite the previous equation as:

$$
\begin{gathered}
\operatorname{logit}\left(p_{i j}\right)=\beta_{0 i}+\beta_{1} z_{i j} \\
\beta_{0 i}=\beta_{00}+\beta_{01} x_{i}+u_{i}
\end{gathered}
$$

$\beta_{0 i}$, the random intercept varies among the level-2 units, with a mean of $\beta_{00}$ conditional on $x$. This random intercept represents the combined effect of potential omitted subject-specific covariates that causes some individuals to be more exposed to fuel vulnerability depending on their type of heating equipment, and indirectly their category of housing ${ }^{14}$.

The LR test confirms the relevance of the two-level random-intercept model. Our results appear to be robust, even after taking into account the possible non independence in the data, due to the type of heating system, or the different categories of housing. Results are reported in appendix E.

Compared with results exposed above, the location appears more significant, implying that living in areas with comfortable temperatures is determinant in the exposure to fuel poverty. This last regression shows that the type of housing, and probably indirectly the quality of the build, is a factor that makes a lot of sense in some regions.

\subsection{Policy implications}

A policy targeting vulnerable individuals on the margin of poverty is essential to reduce the extent of fuel poverty in France and relevant because the at-risk population can be clearly identified. For the population identified in the econometric analysis, the cost of energy is the factor that triggers poverty. Therefore, a specific policy could be implemented to help households located just below the poverty line and help them shift above the threshold. However, we realize that the precise targeting of policy intervention involves trade-offs

\footnotetext{
${ }^{14}$ The random varying intercept model has been also estimated using the type of housing as cluster variable. For reasons of clarity, results have not been reproduced here, but are available on request. Results differ only slightly for the cooking energy variable.
} 
associated with targeting support at one group of households over another. This means that the very poor households under the after fuel cost poverty approach $(17.59 \%$ that were already poor only based on their income level) are not eligible for fuel poverty support policies. However, we consider that this section of the population could benefit from broader transfer policies to improve their standard of living. In this perspective, the government' $s$ role is to deliver an effective policy that focuses on the roots of fuel poverty and drives action to alleviate the problem in the long term.

Finally our results suggest the way forward for the reduction of fuel vulnerability: vulnerable individuals cumulate financial hardships and low-energy efficient housing but are not poor a priori. Consequently, providing financial support for improving the housing energy efficiency could be a relevant measure to reduce the fuel vulnerability. However, until now policies to reduce fuel poverty were based mainly on the observation of the $10 \%$ ratio. We just explained above limitations of this ratio, and exposed why targeted fuel vulnerability would be more efficient.

Three broad types of policy are usually conducted to tackle fuel poverty: price-based, income-based and energy-efficiency improvement policies.

Price-based policy consists in reducing the price paid by households for energy. This type of policy is already applied in France, for example, through the social energy tariffs for lowincome households ${ }^{15}$, which have opened up the right to a reduction in electricity bills since 2005 and natural gas bills since 2008. At the end of 2012, more than 1.8 million French households benefitted from this measure. These aids are funded by all energy consumers. This policy would be expected to bring some households out of fuel poverty, reducing the headcount and the poverty gap. But there are limits to the application of this policy. The eligibility criteria are only based on households' income resources and not on fuel poverty indicators. In the econometric analysis, we emphasize the fact that it is crucial to look closely at energy costs related to disposal income. Also, targeting the type of energy used, or the type of heating equipment, both of which are factors that determine fuel vulnerability, is not taken into account. Moreover, as these measures are funded by energy consumers, they can negatively impact vulnerable households in hardship situations that do not benefit from these measures. The debate on whether interventions should be funded by energy consumers or taxes is important. The tax-funded option would allow policy funding to be progressive and better protect vulnerable consumers.

Policies that increase income would lead to reduced levels of fuel poverty. However, income transfer for low-income households could be rationally spent on any other expenditure. In France, with housing allowances that tackle poverty in general, poorer households can also receive an income supplement to help them cover expenditure on energy and water. This type of policy does not specifically focus on fuel-poor and vulnerable households. Also, such payments would only have a one-off impact on fuel poverty unless repeated. With such curative measures, root causes related to housing characteristics (types of heating system, absence of double glazed windows, poor insulation of the roof) are not addressed as they are limited in scope and were not designed for fuel vulnerable households. They do not represent a sustainable answer to fuel poverty reduction in France. In addition, the amount of such aids is too small (about $10 \%$ of the total energy bill). If these types of measures are to be implemented in the short term, they should be supplemented by preventive policies that focus on improving the energy efficiency of housing.

The main focus of fuel poverty policies should be to reduce the energy consumption of housing in order to sustainably reduce vulnerable households' energy bills. This is in line with the "Grenelle de l'environnement" objective to reduce energy consumptions by $38 \%$ in the housing stock by 2020 . To reach this target, the government has introduced several

\footnotetext{
${ }^{15}$ Since December 2012 monthly income should not exceed $€ 967$ for a single person
} 
measures to incentivize energy-efficiency. The interest-free loan (L'éco-prêt à taux zéro) and the sustainable development tax credit (crédit d'impôt développement durable) are incentives to carry out renovation work or install efficient equipment. The first of these allows homeowners, without any income conditions, to borrow up to $€ 30,000$ for renovation work in their main residence built before 1990. The second is for all households (tax payers, non-tax payers). They can deduct a percentage of their spending on energy efficiency improvements in their principal house from their taxable income (or receive a tax credit). These two tools aim to reduce energy consumption but as they do not focus on fuel poor households they are not well suited to reducing the extent of fuel poverty in France, especially because homeowners tend to be less fuel vulnerable according to our empirical work. In many cases, fuel poor households have a borrower profile that is not reassuring for banks that provide interest-free loans. These measures tend to benefit households with higher incomes. Similarly, accessing the sustainable development tax credit is difficult for low-income households that cannot usually afford to advance funds for renovation work.

We believe that if the policy maker clearly identifies those who are exposed specifically and uniquely because of fuel costs, it would be efficient in terms of fuel poverty reduction to provide them with incentives to save energy and carry out restoration works. This could take the form of aids for natural mains gas connection, subsidies for boiler replacements and roof and wall insulation, etc. Fuel poor households can be occupied by owners, landlords or tenants, and therefore the policy should not be too restrictive, and could be in some cases unrelated to the home' $\mathrm{s}$ ownership. If one considers that the role of the welfare State is promote wellbeing and consequently to devote public spending to reduce fuel vulnerability, one can imagine agreements between the State and some boilers providers, some buildings craftsmen, etc., in order to propose equipments at an affordable price.

\section{Conclusion}

This paper estimates the scale of fuel poverty in France under diverse measures and identifies the vulnerable households at risk of falling into poverty only because of energy costs.

The three measurement approaches selected (the 10\% approach, the Hills approach and the after fuel cost poverty approach) led to contrasting results in terms of the extent of fuel poverty and the composition of the fuel poor.

Based on the results of the French housing survey (Insee, 2006), the results show that $16.6 \%$ of the French population is fuel poor under the 10\% approach, $20.9 \%$ under the after fuel cost poverty approach and $9.2 \%$ under the Hills approach. $7.76 \%$ of the population emerge as fuel poor according to the three approaches.

The approaches do not depict the same fuel poverty picture. The after fuel cost poverty approach, which is a more global approach to poverty, mainly captures active individuals who are tenants and usually living alone in apartments, while the two other approaches, focusing more on energy expenditure, tend to target inactive retirees who own their homes and live in detached houses with individual boilers as their main heating systems using domestic fuel.

Furthermore, we conducted an income-based analysis in order to characterize the most vulnerable households. A renewed targeting of the fuel poor households was proposed in the empirical part of the paper. We identified those below the poverty line after the fuel bill and selected a sample of households that were not poverty exposed before the fuel bill. This enabled us to put a greater focus on individuals who fall into poverty solely as a result of energy costs. Logistic, complementary log-log and mixed effect logistic models were used to analyze the impact of certain households and dwelling characteristics on the probability of 
falling into poverty. This detailed consideration of the characteristics is important in understanding which type of households should be prioritized for support through policies.

The study suggests that living alone is associated with a high probability of falling into fuel poverty. Moreover, retired people living alone are significantly exposed to fuel poverty. Being a homeowner and highly educated is associated with lower exposure to fuel poverty. The heating system equipment and the type of energy used for cooking are key elements that influence the probability of falling into fuel poverty. Using an individual boiler and cooking with butane/propane are associated with a high probability of being fuel poor, while collective boilers, district heating systems and cooking with city gas (natural gas) seem to protect against fuel poverty. Moreover, a low energy performance home is a significant fuel poverty factor. Only housing built after 1974 (after the first thermal regulation in France) decreases the exposure to fuel poverty.

Our study points the way towards new research avenues. For the moment, the analysis is based on actual fuel expenditure because of a lack of data in France. Yet we cannot be sure that these costs are representative of an adequate level of well-being: would a household spend more to warm their dwelling if they could? We can assume so, because $29 \%$ to $36 \%$ of the fuel poor (depending on the definition) claim that they suffer from cold due to heating limitations. These heating limitations will be taken into account in further researches by using appropriate econometric estimates. Censored regression models, namely Tobit model, are designed to estimate the relationship between variables when there is censoring in the dependent variable. 
Appendix A Characteristics of the fuel poor under three different measures

\begin{tabular}{|c|c|c|c|c|c|}
\hline & & $\begin{array}{l}\text { Poor (after fuel } \\
\text { cost poverty } \\
\text { approach) }\end{array}$ & $\begin{array}{c}\text { Poor ( } 10 \% \\
\text { ratio approach) }\end{array}$ & $\begin{array}{l}\text { Poor (Hills } \\
\text { approach) }\end{array}$ & Population \\
\hline \multirow{8}{*}{$\begin{array}{l}\text { Professional } \\
\text { categories of the } \\
\text { head of household }\end{array}$} & Farmers & $1 \%$ & $2 \%$ & $2 \%$ & $1 \%$ \\
\hline & $\begin{array}{l}\text { Shopkeepers, } \\
\text { Craftspeople, } \\
\text { entrepreneurs }\end{array}$ & $4 \%$ & $4 \%$ & $4 \%$ & $4 \%$ \\
\hline & $\begin{array}{l}\text { Managers and profess. } \\
\text { occupations }\end{array}$ & $3 \%$ & $2 \%$ & $3 \%$ & $12 \%$ \\
\hline & $\begin{array}{l}\text { Intermediate } \\
\text { occupations }\end{array}$ & $8 \%$ & $5 \%$ & $6 \%$ & $16 \%$ \\
\hline & Employees & $19 \%$ & $11 \%$ & $14 \%$ & $14 \%$ \\
\hline & Blue collar workers & $21 \%$ & $12 \%$ & $16 \%$ & $16 \%$ \\
\hline & Pensioners & $30 \%$ & $54 \%$ & $45 \%$ & $33 \%$ \\
\hline & Other inactive people & $14 \%$ & $10 \%$ & $10 \%$ & $4 \%$ \\
\hline \multirow{4}{*}{$\begin{array}{l}\text { Household } \\
\text { composition }\end{array}$} & Person living alone & $43 \%$ & $49 \%$ & $48 \%$ & $33 \%$ \\
\hline & $\begin{array}{l}\text { Multi-person } \\
\text { households }\end{array}$ & $4 \%$ & $4 \%$ & $3 \%$ & $3 \%$ \\
\hline & $\begin{array}{l}\text { Single parent with } \\
\text { dependent children }\end{array}$ & $12 \%$ & $8 \%$ & $10 \%$ & $6 \%$ \\
\hline & $\begin{array}{l}\text { Family (with or } \\
\text { without children) }\end{array}$ & $40 \%$ & $40 \%$ & $38 \%$ & $58 \%$ \\
\hline \multirow{3}{*}{$\begin{array}{l}\text { Housing } \\
\text { occupation status }\end{array}$} & $\begin{array}{l}\text { Homeowner (with or } \\
\text { without mortgage) }\end{array}$ & $32 \%$ & $66 \%$ & $53 \%$ & $59 \%$ \\
\hline & Rent free & $4 \%$ & $5 \%$ & $4 \%$ & $4 \%$ \\
\hline & Tenant & $63 \%$ & $29 \%$ & $43 \%$ & $37 \%$ \\
\hline \multirow{5}{*}{ Dwelling type } & Detached house & $43 \%$ & $76 \%$ & $71 \%$ & $58 \%$ \\
\hline & Flat & $54 \%$ & $22 \%$ & $27 \%$ & $41 \%$ \\
\hline & $\begin{array}{l}\text { Room in a collective } \\
\text { structure (seniors } \\
\text { residence, group home) }\end{array}$ & $1 \%$ & $0 \%$ & $0 \%$ & $0 \%$ \\
\hline & Farm & $0 \%$ & $1 \%$ & $0 \%$ & $0 \%$ \\
\hline & Others & $2 \%$ & $1 \%$ & $1 \%$ & $1 \%$ \\
\hline \multirow{6}{*}{ Heating system } & Individual boiler & $38 \%$ & $65 \%$ & $60 \%$ & $47 \%$ \\
\hline & District heating & $2 \%$ & $0 \%$ & $0 \%$ & $2 \%$ \\
\hline & Collective boiler & $21 \%$ & $4 \%$ & $3 \%$ & $16 \%$ \\
\hline & $\begin{array}{c}\text { Mixed boiler } \\
\text { (collective }+ \text { individual } \\
\text { heating) }\end{array}$ & $1 \%$ & $0 \%$ & $0 \%$ & $1 \%$ \\
\hline & $\begin{array}{l}\text { Individual electric } \\
\text { heating }\end{array}$ & $30 \%$ & $23 \%$ & $27 \%$ & $27 \%$ \\
\hline & None of the above & $8 \%$ & $8 \%$ & $5 \%$ & $6 \%$ \\
\hline \multirow{2}{*}{$\begin{array}{l}\text { Energy type for } \\
\text { individual boiler }\end{array}$} & Domestic fuel & $25.15 \%$ & $45.92 \%$ & $36.35 \%$ & $30.37 \%$ \\
\hline & City gas & $62.86 \%$ & $41.27 \%$ & $52.87 \%$ & $59.06 \%$ \\
\hline
\end{tabular}




\begin{tabular}{|c|c|c|c|c|c|}
\hline & Butane, propane & $2.57 \%$ & $7.14 \%$ & $4.82 \%$ & $3.90 \%$ \\
\hline & Coal & $0.42 \%$ & $0.46 \%$ & $0.23 \%$ & $0.32 \%$ \\
\hline & Wood & $1.79 \%$ & $2.70 \%$ & $2.15 \%$ & $2.19 \%$ \\
\hline & Electricity & $5.73 \%$ & $3.81 \%$ & $5.19 \%$ & $4.06 \%$ \\
\hline & Others & $1.48 \%$ & $0.00 \%$ & $0.00 \%$ & $0.10 \%$ \\
\hline \multirow{6}{*}{$\begin{array}{l}\text { Energy used for } \\
\text { cooking }\end{array}$} & City gas & $20 \%$ & $21 \%$ & $25 \%$ & $25 \%$ \\
\hline & Butane Propane & $43 \%$ & $39 \%$ & $38 \%$ & $24 \%$ \\
\hline & Electricity & $12 \%$ & $16 \%$ & $16 \%$ & $27 \%$ \\
\hline & $\begin{array}{l}\text { Electricity and City } \\
\text { gas }\end{array}$ & $5 \%$ & $6 \%$ & $7 \%$ & $11 \%$ \\
\hline & Electricity and Butane & $18 \%$ & $17 \%$ & $12 \%$ & $12 \%$ \\
\hline & Other & $2 \%$ & $1 \%$ & $1 \%$ & $0 \%$ \\
\hline \multirow{5}{*}{$\begin{array}{c}\% \text { of } \\
\text { respondents } \\
\text { claiming to suffer } \\
\text { from cold due } \\
\text { to... }\end{array}$} & $\begin{array}{l}\text { Insufficient heating } \\
\text { equipment }\end{array}$ & $38 \%$ & $30 \%$ & $34 \%$ & $32 \%$ \\
\hline & Equipment breakdown & $12 \%$ & $13 \%$ & $13 \%$ & $19 \%$ \\
\hline & $\begin{array}{l}\text { Heating under- } \\
\text { consumption }\end{array}$ & $29 \%$ & $36 \%$ & $36 \%$ & $21 \%$ \\
\hline & Poor insulation & $45 \%$ & $43 \%$ & $47 \%$ & $41 \%$ \\
\hline & Other reasons & $7 \%$ & $11 \%$ & $8 \%$ & $15 \%$ \\
\hline
\end{tabular}

Source: Enquête Logement 2006,

Key to read: $33 \%$ of the population is retired, while 54 and $45 \%$ are pensionners among fuel poor according respectively to the $10 \%$ and the Hills 'approaches. They are consequently overrepresented among fuel poor defined using these definitions. On the contrary, they are only 30 among the fuel poor according to the after fuel cost approach.

Appendix B Descriptive statistics of sample selected for the estimates

\begin{tabular}{cccc} 
& Poverty rate & Poverty gap & $\begin{array}{c}\text { Poverty } \\
\text { severity }\end{array}$ \\
\hline Couple of active people & $0,86 \%$ & 0,00052 & 0,00008 \\
Retired couple & $2,89 \%$ & 0,00204 & 0,00025 \\
Lone active & $2,07 \%$ & 0,00133 & 0,00016 \\
Lone retired & $6,93 \%$ & 0,00562 & 0,00093 \\
\hline Having dependant children & $1,78 \%$ & 0,00091 & 0,00013 \\
\hline Homeowners & $2,84 \%$ & 0,00252 & 0,00043 \\
\hline $\begin{array}{c}\text { No diploma } \\
\text { Intermediate educational } \\
\text { attainment }\end{array}$ & $6,96 \%$ & 0,00471 & 0,00059 \\
High educational & $0,76 \%$ & 0,00052 & 0,00007 \\
attainment & $0,62 \%$ & 0,00053 & 0,00009 \\
\hline Individual boiler & $3,73 \%$ & 0,0029 & 0,00048
\end{tabular}




\begin{tabular}{|c|c|c|c|}
\hline District heating system & $0,68 \%$ & 0,00048 & 0,00004 \\
\hline Collective boiler & $0,28 \%$ & 0,00038 & 0,0001 \\
\hline Mixed heating system & $0,15 \%$ & 0,00001 & 0 \\
\hline $\begin{array}{l}\text { Heating individual electric } \\
\text { convectors }\end{array}$ & $2,16 \%$ & 0,00113 & 0,00012 \\
\hline Renewable energy & $0,48 \%$ & 0,00073 & 0,00014 \\
\hline Cooking : town gas stream & $2,36 \%$ & 0,00159 & 0,00023 \\
\hline $\begin{array}{l}\text { Cooking : butane and } \\
\text { propane }\end{array}$ & $4,95 \%$ & 0,0036 & 0,00058 \\
\hline Cooking: electricity only & $1,19 \%$ & 0,00073 & 0,00011 \\
\hline $\begin{array}{l}\text { Cooking : Electricity and } \\
\text { town gas stream }\end{array}$ & $1,17 \%$ & 0,00082 & 0,0001 \\
\hline $\begin{array}{l}\text { Cooking: Electricity and } \\
\text { butane/propane }\end{array}$ & $3,88 \%$ & 0,00346 & 0,00059 \\
\hline $\begin{array}{l}\text { Housing constructed } \\
\text { before } 1950\end{array}$ & $3,67 \%$ & 0,00269 & 0,00041 \\
\hline $\begin{array}{l}\text { Housing constructed } \\
\text { between } 1950 \text { and } 1974\end{array}$ & $2,50 \%$ & 0,00181 & 0,00025 \\
\hline $\begin{array}{l}\text { Housing constructed after } \\
1974\end{array}$ & $1,92 \%$ & 0,00145 & 0,00027 \\
\hline Climate zone 1 & $3,33 \%$ & 0,00241 & 0,00036 \\
\hline Climate zone 2 & $2,25 \%$ & 0,0017 & 0,00025 \\
\hline Climate zone 3 & $3,34 \%$ & 0,00231 & 0,0004 \\
\hline Climate zone 4 & $2,70 \%$ & 0,00208 & 0,00037 \\
\hline Double glazed & $2,35 \%$ & 0,00161 & 0,00025 \\
\hline Poor insulation of the roof & $6,50 \%$ & 0,00508 & 0,00077 \\
\hline Entire sample & $2,76 \%$ & 0,00203 & 0,00032 \\
\hline $\mathrm{N}$ & & 26531 & \\
\hline
\end{tabular}




\section{Appendix C: Presentation of partial results}

\begin{tabular}{|c|c|c|c|c|c|}
\hline Logit & (1) & $(2)$ & (3) & (4) & $(5)$ \\
\hline \multirow{2}{*}{ Active couple $\mathrm{Yes}=1 \mathrm{No}=0$} & $-1,336 * * *$ & $-1,435 * * *$ & $-1,433 * * *$ & $-1,465 * * *$ & $-1,465 * * *$ \\
\hline & $(0,137)$ & $(0,123)$ & $(0,124)$ & $(0,100)$ & $(0,128)$ \\
\hline \multirow{2}{*}{ Retired couple Yes $=1 \mathrm{No}=0$} & $-0,269$ & $-0,311 *$ & $-0,325^{*}$ & $-0,347^{*}$ & $-0,347 *$ \\
\hline & $(0,143)$ & $(0,134)$ & $(0,137)$ & $(0,163)$ & $(0,131)$ \\
\hline \multirow{2}{*}{$\begin{array}{l}\text { Active living alone } \mathrm{Yes}=1 \\
\qquad \mathrm{No}=0\end{array}$} & $-0,320 * *$ & $-0,230$ & $-0,234^{*}$ & $-0,201$ & $-0,201$ \\
\hline & $(0,115)$ & $(0,116)$ & $(0,116)$ & $(0,126)$ & $(0,143)$ \\
\hline \multirow{2}{*}{$\begin{array}{l}\text { Retired living alone } \text { Yes }=1 \\
\text { No }=0\end{array}$} & $0,475 * * *$ & $0,530 * * *$ & $0,508 * * *$ & $0,531 * * *$ & $0,531 * * *$ \\
\hline & $(0,116)$ & $(0,114)$ & $(0,122)$ & $(0,129)$ & $(0,117)$ \\
\hline \multirow{2}{*}{ Children in the household } & $0,228 * * *$ & $0,201 * * *$ & $0,200 * * *$ & $0,190 * * *$ & $0,190 * * *$ \\
\hline & $(0,0448)$ & $(0,0427)$ & $(0,0363)$ & $(0,0549)$ & $(0,0399)$ \\
\hline \multirow{2}{*}{ Homeowner Yes $=1 \mathrm{No}=1$} & $-0,214^{*}$ & $-0,499 * * *$ & $-0,490 * * *$ & $-0,587 * * *$ & $-0,587 * * *$ \\
\hline & $(0,0887)$ & $(0,114)$ & $(0,0810)$ & $(0,0827)$ & $(0,0847)$ \\
\hline \multirow{2}{*}{ No diploma Yes $=1 \mathrm{No}=0$} & $1,091 * * *$ & $1,157 * * *$ & $1,145 * * *$ & $1,035 * * *$ & $1,035 * * *$ \\
\hline & $(0,141)$ & $(0,153)$ & $(0,152)$ & $(0,127)$ & $(0,170)$ \\
\hline \multirow{2}{*}{$\begin{array}{l}\text { Low level of diploma Yes }=1 \\
\qquad \text { No }=0\end{array}$} & $0,455^{* *}$ & $0,479 * *$ & $0,481 * *$ & $0,397 * *$ & $0,397 * *$ \\
\hline & $(0,148)$ & $(0,141)$ & $(0,155)$ & $(0,120)$ & $(0,153)$ \\
\hline A level Yes=1 $\mathrm{No}=0$ & Ref. & Ref. & Ref. & Ref. & Ref. \\
\hline \multirow{2}{*}{$\begin{array}{l}\text { Intermediate educational level } \\
\text { Yes }=1 \mathrm{No}=0\end{array}$} & $-0,403$ & $-0,411$ & $-0,412$ & $-0,388$ & $-0,381^{*}$ \\
\hline & $(0,222)$ & $(0,230)$ & $(0,238)$ & $(0,211)$ & $(0,194)$ \\
\hline \multirow{2}{*}{ Master's degree Yes $=1 \mathrm{No}=0$} & $-0,986 * * *$ & $-0,989 * * *$ & $-1,000 * * *$ & $-0,891 * * *$ & $-0,891 * * *$ \\
\hline & $(0,237)$ & $(0,277)$ & $(0,216)$ & $(0,202)$ & $(0,220)$ \\
\hline \multirow{2}{*}{ Individual boiler $\mathrm{Yes}=1 \mathrm{No}=0$} & & $0,393 * * *$ & $0,355 * * *$ & $0,592 * * *$ & $0,592 * * *$ \\
\hline & & $(0,080)$ & $(0,102)$ & $(0,105)$ & $(0,125)$ \\
\hline \multirow{2}{*}{ District heating Yes $=1 \mathrm{No}=0$} & & $-1,857 * * *$ & $-1,900 * * *$ & $-1,536^{*}$ & $-1,536 * *$ \\
\hline & & $(0,518)$ & $(0,575)$ & $(0,744)$ & $(0,468)$ \\
\hline \multirow{2}{*}{ Collective boiler Yes $=1 \mathrm{No}=0$} & & $-2.254 * * *$ & $-2.301 * * *$ & $-1,953 * * *$ & $-1,953 * * *$ \\
\hline & & $(0,225)$ & $(0,327)$ & $(0,254)$ & $(0,402)$ \\
\hline \multirow{2}{*}{ Mixed heating $\mathrm{Yes}=1 \mathrm{No}=0$} & & $-1.285^{*}$ & $-1,221 * *$ & $-1,017 * *$ & $-1,017^{*}$ \\
\hline & & $(0,507)$ & $(0,421)$ & $(0,366)$ & $(0,426)$ \\
\hline $\begin{array}{l}\text { Heating individual electric } \\
\text { convectors Yes }=1 \mathrm{No}=1\end{array}$ & & Ref. & Ref. & Ref. & Ref. \\
\hline \multirow{2}{*}{$\begin{array}{l}\text { Other type of heating system } \\
\qquad \text { Yes }=1 \text { No=1 }\end{array}$} & & $0,460 *$ & $0,408 *$ & 0,273 & 0,273 \\
\hline & & $(0,181)$ & $(0,180)$ & $(0,162)$ & $(0,163)$ \\
\hline \multirow{2}{*}{$\begin{array}{l}\text { Renewable energy Yes }=1 \\
\text { No=1 }\end{array}$} & & $-0,748$ & $-0,715$ & $-0,665$ & $-0,665$ \\
\hline & & $(0,600)$ & $(0,597)$ & $(0,558)$ & $(0,574)$ \\
\hline \multirow{2}{*}{$\begin{array}{l}\text { Housing constructed before } \\
1949 \text { Yes }=1 \mathrm{No}=1\end{array}$} & & & 0.0129 & $-0,0241$ & $-0,0241$ \\
\hline & & & $(0,099)$ & $(0,0840)$ & $(0,111)$ \\
\hline $\begin{array}{l}\text { Housing constructed between } \\
1950 \text { and } 1974 \text { Yes=1 No=1 }\end{array}$ & & & Ref. & Ref. & Ref. \\
\hline \multirow{2}{*}{$\begin{array}{l}\text { Housing constructed after } \\
1974 \text { Yes }=1 \mathrm{No}=1\end{array}$} & & & $-0,227 *$ & $-0,240 * *$ & $-0,243$ \\
\hline & & & $(0,114)$ & $(0,0903)$ & $(0,140)$ \\
\hline \multirow{2}{*}{$\begin{array}{l}\text { Cooking: town gas streams } \\
\text { Yes }=1 \mathrm{No}=1\end{array}$} & & & & 0,119 & 0,109 \\
\hline & & & & $(0,119)$ & $(0,136)$ \\
\hline
\end{tabular}


Cooking: butane-propane

$0,902 * * * \quad 0,893 * * *$

Yes $=1 \mathrm{No}=1$

$(0,115) \quad(0,130)$

Cooking: only electricity Yes $=1 \mathrm{No}=1$

Cooking: Electricity and town

Ref.

Ref.

gas stream Yes $=1 \mathrm{No}=1$

$-0,557 * * \quad-0,545 * *$

Cooking: Electricity and

$(0,193) \quad(0,211)$

butane/propane Yes $=1 \mathrm{No}=1$

$0,619 * * * \quad 0,624 * * *$

$(0,137) \quad(0,170)$

$1,359 \quad 1,355 * * *$

Cooking: other $\mathrm{Yes}=1 \mathrm{No}=0$

$(0,702)$

$(0,384)$

Climate zone 1 Yes=1 No=0

Ref.

Climate zone 2 Yes $=1 \mathrm{No}=0$

$-0,222 * *$

$(0,0841)$

$-0,231^{*}$

Climate zone $3 \mathrm{Yes}=1 \mathrm{No}=0$

Climate zone 4 Yes $=1 \mathrm{No}=0$

\begin{tabular}{|c|c|c|c|c|c|}
\hline Intercept & $\begin{array}{c}-3,687 * * * \\
(0,157)\end{array}$ & $\begin{array}{c}-3,635 * * * \\
(0,154)\end{array}$ & $\begin{array}{c}-3,541 * * * \\
(0,220)\end{array}$ & $\begin{array}{c}-3,925 * * * \\
(0,186)\end{array}$ & $\begin{array}{c}-3,817 * * * \\
(0,206)\end{array}$ \\
\hline $\mathrm{N}$ & & & 26531 & & \\
\hline LL & -2914.2 & -2787.7 & -27779.5 & -2718.5 & -2714.2 \\
\hline
\end{tabular}

Robust standard errors are reported in brackets

\begin{tabular}{|c|c|c|c|c|c|}
\hline cloglog & (1) & (2) & (3) & (4) & (5) \\
\hline \multirow{2}{*}{ Active couple $\mathrm{Yes}=1 \mathrm{No}=0$} & $-1,311 * * *$ & $-1,401 * * *$ & $-1,398 * * *$ & $-1,429 * * *$ & $-1,408 * * *$ \\
\hline & $(0,133)$ & $(0,146)$ & $(0,144)$ & $(0,138)$ & $(0,101)$ \\
\hline \multirow{2}{*}{ Retired couple Yes $=1 \mathrm{No}=0$} & $-0,264$ & $-0,305^{*}$ & $-0,319 * *$ & $-0,341 *$ & $-0,322 * *$ \\
\hline & $(0,155)$ & $(0,119)$ & $(0,110)$ & $(0,135)$ & $(0,121)$ \\
\hline \multirow{2}{*}{$\begin{array}{l}\text { Active living alone } \mathrm{Yes}=1 \\
\qquad \mathrm{No}=0\end{array}$} & $-0,312 *$ & $-0,220$ & $-0,225$ & $-0,194$ & $-0,172$ \\
\hline & $(0,146)$ & $(0,129)$ & $(0,139)$ & $(0,154)$ & $(0,096)$ \\
\hline \multirow{2}{*}{$\begin{array}{l}\text { Retired living alone } \mathrm{Yes}=1 \\
\text { No }=0\end{array}$} & $0,463 * * *$ & $0,512 * * *$ & $0,490 * * *$ & $0,504 * * *$ & $0,518 * * *$ \\
\hline & $(0,129)$ & $(0,123)$ & $(0,102)$ & $(0,116)$ & $(0,117)$ \\
\hline \multirow{2}{*}{ Children in the household } & $0,221 * * *$ & $0,192 * * *$ & $0,190 * * *$ & $0,183 * * *$ & $0,184 * * *$ \\
\hline & $(0,0425)$ & $(0,0387)$ & $(0,0407)$ & $(0,0445)$ & $(0,0407)$ \\
\hline \multirow{2}{*}{ Homeowner $\mathrm{Yes}=1 \mathrm{No}=1$} & $-0,206^{*}$ & $-0,481 * * *$ & $-0,472 * * *$ & $-0,561 * * *$ & $-0,555^{* * * *}$ \\
\hline & $(0,0965)$ & $(0,0645)$ & $(0,0883)$ & $(0,102)$ & $(0,0691)$ \\
\hline \multirow{2}{*}{ No diploma Yes $=1 \mathrm{No}=0$} & $1,067 * * *$ & $1,123 * * *$ & $1,111 * * *$ & $1,002 * * *$ & $0.988 * * *$ \\
\hline & $(0,139)$ & $(0,160)$ & $(0,169)$ & $(0,140)$ & $(0,124)$ \\
\hline \multirow{2}{*}{$\begin{array}{l}\text { Low level of diploma Yes }=1 \\
\qquad \mathrm{No}=0\end{array}$} & $0,448 * * *$ & $0,471 * * *$ & $0,472 * * *$ & $0,392 * *$ & $0,392 * * *$ \\
\hline & $(0,122)$ & $(0,134)$ & $(0,135)$ & $(0,140)$ & $(0,111)$ \\
\hline
\end{tabular}

A level Yes $=1 \mathrm{No}=0$

Ref.

Ref.

Ref.

Ref.

Ref. 


\begin{tabular}{|c|c|c|c|c|c|}
\hline $\begin{array}{l}\text { Intermediate educational level } \\
\quad \mathrm{Yes}=1 \mathrm{No}=0\end{array}$ & $\begin{array}{l}-0,399 * \\
(0,192)\end{array}$ & $\begin{array}{l}-0,405 \\
(0,245)\end{array}$ & $\begin{array}{l}-0,406 \\
(0,286)\end{array}$ & $\begin{array}{l}-0,379 * \\
(0,168)\end{array}$ & $\begin{array}{l}-0,373 \\
(0,203)\end{array}$ \\
\hline Master's degree & $\begin{array}{c}-0,979 * * * \\
(0,211)\end{array}$ & $\begin{array}{c}-0,978 * * * \\
(0,192)\end{array}$ & $\begin{array}{c}-0.989 * * * \\
(0,226)\end{array}$ & $\begin{array}{c}-0,881 * * * \\
(0,183)\end{array}$ & $\begin{array}{c}-0,859 * * * \\
(0,129)\end{array}$ \\
\hline Individual boiler $\mathrm{Yes}=1 \mathrm{No}=0$ & & $\begin{array}{l}0,384 * * * \\
(0,0879)\end{array}$ & $\begin{array}{c}0,347 * * * \\
(0,102)\end{array}$ & $\begin{array}{c}0,573 * * * \\
(0,116)\end{array}$ & $\begin{array}{c}0,571 * * * \\
(0,123)\end{array}$ \\
\hline District heating Yes $=1 \mathrm{No}=0$ & & $\begin{array}{c}-1,825 * * * \\
(0,478)\end{array}$ & $\begin{array}{c}-1,866 * * * \\
(0,555)\end{array}$ & $-1,509 * * *$ & $\begin{array}{r}-1,469 * * * \\
(0,532)\end{array}$ \\
\hline Collective boiler Yes $=1 \mathrm{No}=0$ & & $\begin{array}{c}-2.224 * * * \\
(0,254)\end{array}$ & $\begin{array}{c}-2.268 * * * \\
(0,345)\end{array}$ & $\begin{array}{c}-1,927 * * * \\
(0,311)\end{array}$ & $\begin{array}{c}-1,907 * * * \\
(0,331)\end{array}$ \\
\hline Mixed heating Yes $=1 \mathrm{No}=0$ & & $\begin{array}{c}-1.258 * * \\
(0,436)\end{array}$ & $\begin{array}{l}-1,192 * \\
(0,463)\end{array}$ & $\begin{array}{c}-0,994 * * \\
(0,451)\end{array}$ & $\begin{array}{r}-0.963 * \\
(0,445)\end{array}$ \\
\hline $\begin{array}{l}\text { Heating individual electric } \\
\text { convectors Yes }=1 \mathrm{No}=1\end{array}$ & & Ref. & Ref. & Ref. & Ref. \\
\hline $\begin{array}{l}\text { Other type of heating system } \\
\text { Yes }=1 \text { No=1 }\end{array}$ & & $\begin{array}{c}0,446 * * * \\
(0,127)\end{array}$ & $\begin{array}{l}0,394 * * \\
(0,135)\end{array}$ & $\begin{array}{c}0,263 \\
(0,149)\end{array}$ & $\begin{array}{c}0,224 \\
(0,159)\end{array}$ \\
\hline $\begin{array}{l}\text { Renewable energy Yes=1 } \\
\text { No=1 }\end{array}$ & & $\begin{array}{l}-0,739 \\
(0,701) \\
\end{array}$ & $\begin{array}{l}-0,706 \\
(0,589) \\
\end{array}$ & $\begin{array}{l}-0,663 \\
(0,592) \\
\end{array}$ & $\begin{array}{l}-0,652 \\
(0,526) \\
\end{array}$ \\
\hline $\begin{array}{l}\text { Housing constructed before } \\
1949 \text { Yes }=1 \mathrm{No}=1\end{array}$ & & & $\begin{array}{c}0.0139 \\
(0,0929)\end{array}$ & $\begin{array}{l}-0,0184 \\
(0,0966)\end{array}$ & $\begin{array}{l}-0,0190 \\
(0,0938)\end{array}$ \\
\hline $\begin{array}{l}\text { Housing constructed between } \\
1950 \text { and } 1974 \text { Yes=1 No=1 }\end{array}$ & & & Ref. & Ref. & Ref. \\
\hline $\begin{array}{l}\text { Housing constructed after } \\
1974 \mathrm{Yes}=1 \mathrm{No}=1\end{array}$ & & & $\begin{array}{l}-0,219 \\
(0,126)\end{array}$ & $\begin{array}{l}-0,229 * \\
(0,106)\end{array}$ & $\begin{array}{l}-0,233 \\
(0,132)\end{array}$ \\
\hline $\begin{array}{l}\text { Cooking: town gas streams } \\
\text { Yes }=1 \mathrm{No}=1\end{array}$ & & & & $\begin{array}{c}0,126 \\
(0,137)\end{array}$ & $\begin{array}{c}0,117 \\
(0,151)\end{array}$ \\
\hline $\begin{array}{l}\text { Cooking: butane-propane } \\
\text { Yes }=1 \mathrm{No}=1\end{array}$ & & & & $\begin{array}{c}0,877 * * * \\
(0,107)\end{array}$ & $\begin{array}{c}0,869 * * * \\
(0,139)\end{array}$ \\
\hline $\begin{array}{l}\text { Cooking: only electricity } \\
\text { Yes }=1 \mathrm{No}=1\end{array}$ & & & & Ref. & Ref. \\
\hline $\begin{array}{l}\text { Cooking:Electricity and town } \\
\text { gas stream Yes }=1 \mathrm{No}=1\end{array}$ & & & & $\begin{array}{c}-0,538 * * \\
(0,180)\end{array}$ & $\begin{array}{c}-0,526 * * \\
(0,187)\end{array}$ \\
\hline $\begin{array}{r}\text { Cooking: Electrivity and } \\
\text { butane/propane Yes=1 No=1 }\end{array}$ & & & & $\begin{array}{c}0,608 * * * \\
(0,122)\end{array}$ & $\begin{array}{c}0,613 * * * \\
(0,157)\end{array}$ \\
\hline Cooking: other $\mathrm{Yes}=1 \mathrm{No}=0$ & & & & $\begin{array}{r}1,31 * \\
(0,528) \\
\end{array}$ & $\begin{array}{c}1,3^{*} \\
(0,582)\end{array}$ \\
\hline Climate zone 1 Yes $=1 \mathrm{No}=0$ & & & & & Ref. \\
\hline Climate zone $2 \mathrm{Yes}=1 \mathrm{No}=0$ & & & & & $\begin{array}{l}-0,208 \\
(0,158)\end{array}$ \\
\hline Climate zone $3 \mathrm{Yes}=1 \mathrm{No}=0$ & & & & & $\begin{array}{l}-0,218 \\
(0,135)\end{array}$ \\
\hline Climate zone $4 \mathrm{Yes}=1 \mathrm{No}=0$ & & & & & $\begin{array}{l}0,0262 \\
(0,160)\end{array}$ \\
\hline
\end{tabular}




\begin{tabular}{|c|c|c|c|c|c|}
\hline Intercept & $\begin{array}{c}-3,701 * * * \\
(0,179)\end{array}$ & $\begin{array}{c}-3,650 * * * \\
(0,150)\end{array}$ & $\begin{array}{c}-3,560 * * * \\
(0,171)\end{array}$ & $\begin{array}{c}-3,940 * * * \\
(0,192)\end{array}$ & $\begin{array}{c}-3,839 * * * \\
(0,262)\end{array}$ \\
\hline $\mathrm{N}$ & & & 26531 & & \\
\hline LL & -2914.4 & -2783.0 & -2779.8 & -2718.6 & -2714.5 \\
\hline
\end{tabular}

\section{Appendix D: marginal effects after complementary log-log model}

Marginal effect after complementary log-log model, for a retiree living alone, homeowner, according to each heating system

Confidence Interval 95\%

Risk of falling below the fuel poverty line

\begin{tabular}{cccc}
\hline Individual boiler Yes $=1 \mathrm{No}=0$ & $3,03 \%$ & $1,62 \%$ & $4,43 \%$ \\
District heating Yes $=1 \mathrm{No}=0$ & $0,44 \%$ & $-0,04 \%$ & $0,92 \%$ \\
Collective boiler Yes $=1 \mathrm{No}=0$ & $0,28 \%$ & $0,05 \%$ & $0,51 \%$ \\
Mixed heating Yes=1 No=0 & $0,76 \%$ & $0,08 \%$ & $1,44 \%$ \\
Heating individual electric convectors Yes=1 & $2,10 \%$ & $1,16 \%$ & $3,05 \%$ \\
No=1 & $1,08 \%$ & $-0,58 \%$ & $2,75 \%$ \\
\hline
\end{tabular}

Source: Enquête Logement 2006,

Key to reading: the marginal effects are calculated for a retiree, living alone, who is a homeowner with no children, the other variables being set at their reference value. A retiree living alone has a probability of $3.03 \%$ of falling into fuel poverty if he has an individual boiler, compared to other heating systems.

Marginal effect after complementary log-log model, for a retiree living alone, who is not homeowner, according to each heating system

Confidence Interval 95\%

Risk of falling below the fuel poverty line

\begin{tabular}{cccc}
\hline Individual boiler Yes $=1 \mathrm{No}=0$ & $5,39 \%$ & $3,05 \%$ & $7,74 \%$ \\
District heating Yes $=1 \mathrm{No}=0$ & $0,79 \%$ & $0,00 \%$ & $1,58 \%$ \\
Collective boiler Yes $=1 \mathrm{No}=0$ & $0,50 \%$ & $0,17 \%$ & $0,84 \%$ \\
Mixed heating Yes $=1 \mathrm{No}=0$ & $1,37 \%$ & $0,23 \%$ & $2,51 \%$ \\
Heating individual electric convectors Yes=1 & $3,76 \%$ & $1,81 \%$ & $5,71 \%$ \\
No=1 & $1,95 \%$ & $-0,65 \%$ & $4,54 \%$ \\
\hline
\end{tabular}

Source : Enquête Logement 2006,

Key to reading: the marginal effects are calculated for a retiree, living alone, who is not homeowner and has no children, the other variables being set at their reference value. A retiree 
living alone has a probability of $5.39 \%$ of falling into fuel poverty if he has an individual boiler compared to other heating systems.

Marginal effect after complementary log-log model, for a single parent family ( 1 active adult) with 1 child, who are not homeowners, according to each heating system

Confidence Interval 95\%

\begin{tabular}{cccc} 
& $\begin{array}{c}\text { Risk of falling below } \\
\text { the fuel poverty line }\end{array}$ & [ & ] \\
\hline Individual boiler Yes $=1 \mathrm{No}=0$ & $3,63 \%$ & $2,29 \%$ & $4,97 \%$ \\
District heating Yes $=1 \mathrm{No}=0$ & $0,53 \%$ & $0,00 \%$ & $1,05 \%$ \\
Collective boiler Yes=1 No=0 & $0,34 \%$ & $0,13 \%$ & $0,55 \%$ \\
Mixed heating Yes=1 No=0 & $0,92 \%$ & $0,00 \%$ & $1,85 \%$ \\
Heating individual electric convectors Yes=1 & $2,53 \%$ & $1,54 \%$ & $3,52 \%$ \\
No=1 & $1,30 \%$ & $0,00 \%$ & $2,88 \%$ \\
Renewable energy Yes=1 No=1
\end{tabular}

Source: Enquête Logement 2006,

Key to reading: the marginal effects are calculated for an active adult living with one child and who is not a homeowner, with the other variables being set at their reference value. This single-parent family has a probability of $3,63 \%$ of falling into fuel poverty if it has an individual boiler, compared to other heating systems.

Marginal effect after complementary log-log model, for a family (active couple +2 children) who do not own their home, according to each heating system

Confidence Interval 95\%

Risk of falling below the fuel poverty line

[ ]

\begin{tabular}{cccc}
\hline Individual boiler Yes=1 No=0 & $1,39 \%$ & $0,68 \%$ & $2,11 \%$ \\
District heating Yes=1 No=0 & $0,20 \%$ & $0,00 \%$ & $0,41 \%$ \\
Collective boiler Yes=1 No=0 & $0,13 \%$ & $0,00 \%$ & $0,21 \%$ \\
Mixed heating Yes=1 No=0 & $0,35 \%$ & $0,00 \%$ & $0,69 \%$ \\
Heating individual electric convectors Yes=1 & $0,97 \%$ & $0,48 \%$ & $1,45 \%$ \\
No=1 & $0,50 \%$ & $0,00 \%$ & $0,99 \%$ \\
\hline
\end{tabular}

Source : Enquête Logement 2006

Key to reading: the marginal effects are calculated for an active couple, living with 2 children and not homeowners, with the other variables being set at their reference value. This family has a probability of $1.39 \%$ of falling into fuel poverty if it has an individual boiler, compared to other heating systems. 
Appendix E : results of the two-level random-intercept model

\begin{tabular}{|c|c|c|}
\hline & $\begin{array}{c}\text { Mixed } \\
\text { effect } \\
\text { Logit } \\
\end{array}$ & $\begin{array}{l}\text { Odd } \\
\text { ratio }\end{array}$ \\
\hline Active couple $\mathrm{Yes}=1 \mathrm{No}=0$ & $\begin{array}{c}-1,411 * * * \\
(0,13)\end{array}$ & $0,244 * * *$ \\
\hline Retired couple $\mathrm{Yes}=1 \mathrm{No}=0$ & $\begin{array}{c}-0,331 * * \\
(0,149)\end{array}$ & $0,718 * *$ \\
\hline Active living alone $\mathrm{Yes}=1 \mathrm{No}=0$ & $\begin{array}{l}-0,204 \\
(0,127)\end{array}$ & 0,815 \\
\hline Retired living alone $\mathrm{Yes}=1 \mathrm{No}=0$ & $\begin{array}{c}0,447 * * * \\
(0,120)\end{array}$ & $1,564 * * *$ \\
\hline Children in the household & $\begin{array}{l}0,221 * * * \\
(0,0455)\end{array}$ & $1,247 * * *$ \\
\hline Homeowner Yes $=1 \mathrm{No}=1$ & $\begin{array}{l}-0,620 * * * \\
(0,0934)\end{array}$ & $0,538 * * *$ \\
\hline No diploma Yes $=1 \mathrm{No}=0$ & $\begin{array}{c}1,054 * * * \\
(0,155)\end{array}$ & $2,869 * * *$ \\
\hline Low level of diploma $\mathrm{Yes}=1 \mathrm{No}=0$ & $\begin{array}{l}0,424 * * \\
(0,144)\end{array}$ & $1,528 * * *$ \\
\hline A level $\mathrm{Yes}=1 \mathrm{No}=0$ & Ref. & Ref. \\
\hline $\begin{array}{l}\text { Intermediate educational level } \mathrm{Yes}=1 \\
\qquad \mathrm{No}=0\end{array}$ & $\begin{array}{l}-0,385^{*} \\
(0,222)\end{array}$ & 0,68 \\
\hline Master's degree $\mathrm{Yes}=1 \mathrm{No}=0$ & $\begin{array}{c}-0,908 * * * \\
(0,224)\end{array}$ & $0,403 * * *$ \\
\hline $\begin{array}{l}\text { Cooking: town gas streams Yes }=1 \\
\qquad \mathrm{No}=1\end{array}$ & $\begin{array}{c}0,13 \\
(0,141)\end{array}$ & 1,143 \\
\hline $\begin{array}{l}\text { Cooking: butane-propane Yes }=1 \\
\text { No=1 }\end{array}$ & $\begin{array}{c}0,818 * * * \\
(0,130)\end{array}$ & $2,266 * * *$ \\
\hline
\end{tabular}

\begin{tabular}{|c|c|c|}
\hline $\begin{array}{l}\text { Cooking: only electricity Yes }=1 \\
\qquad \mathrm{No}=1\end{array}$ & Ref. & Ref. \\
\hline $\begin{array}{l}\text { Cooking:Electricity and town gas } \\
\text { stream Yes }=1 \mathrm{No}=1\end{array}$ & $\begin{array}{l}-0,528 * * \\
(0,198)\end{array}$ & $0,590 * *$ \\
\hline $\begin{array}{c}\text { Cooking: Electrivity and } \\
\text { butane/propane Yes=1 No=1 }\end{array}$ & $\begin{array}{c}0,553 * * * \\
(0,152)\end{array}$ & $1,737 * * *$ \\
\hline Cooking: other Yes $=1 \mathrm{No}=0$ & $\begin{array}{l}1,227 * * \\
(0,499)\end{array}$ & $3,412 * *$ \\
\hline Housing constructed before 1949 & $\begin{array}{l}-0,015 \\
(0,099)\end{array}$ & 0,985 \\
\hline
\end{tabular}

\begin{tabular}{lll}
$\begin{array}{l}\text { Housing constructed between } 1950 \\
\text { and } 1974\end{array}$ & Ref. & Ref. \\
& $-0,179$ & \\
Housing constructed after 1974 & $(0,115)$ & 0,836 \\
\hline
\end{tabular}

Climate zone 1 Yes $=1$ No=0 Ref. Ref. 


\begin{tabular}{|c|c|c|}
\hline Climate zone 2 Yes $=1 \mathrm{No}=0$ & $\begin{array}{c}-0,228 * * \\
(0,105)\end{array}$ & $0,796^{* *}$ \\
\hline Climate zone 3 Yes $=1 \mathrm{No}=0$ & $\begin{array}{l}-0,255^{* *} \\
(0,121)\end{array}$ & $0,775 * *$ \\
\hline Climate zone 4 Yes $=1 \mathrm{No}=0$ & $\begin{array}{l}-0,006 \\
(0,121)\end{array}$ & 0,994 \\
\hline Double-glazed window $\mathrm{Yes}=1 \mathrm{No}=0$ & $\begin{array}{l}-0,280 * * \\
(0,089)\end{array}$ & $0,756^{* *}$ \\
\hline $\begin{array}{l}\text { Poor insulation of the roof Yes }=1 \\
\qquad \mathrm{No}=0\end{array}$ & $\begin{array}{l}0,282 * * \\
(0,105)\end{array}$ & $1,326 * *$ \\
\hline Living area / CU (m2) & $\begin{array}{c}0,0033 * * \\
0,0012\end{array}$ & $1,003 * *$ \\
\hline Intercept & $\begin{array}{c}-4,400 * * * \\
(0,455) \\
\end{array}$ & $0,012 * * *$ \\
\hline $\begin{array}{l}\text { Type of heating system: identity } \\
\text { sd }\end{array}$ & $\begin{array}{c}0,895 \\
(0,292)\end{array}$ & \\
\hline $\begin{array}{l}\text { LR Test vs logistic regression } \\
\qquad \text { chi2(01) }\end{array}$ & $150.09 * * *$ & \\
\hline $\mathrm{N}$ & 26531 & \\
\hline LL & -2713.7 & \\
\hline \multicolumn{3}{|c|}{$\begin{array}{l}* \mathrm{p}<0.1 ; * * \mathrm{p}<0.05 ; * * * \mathrm{p}<0.01 \text {. } \\
\text { Robust standard errors are reported in brackets. } \\
\text { Coefficients calculated with } 10 \text { integration points }\end{array}$} \\
\hline
\end{tabular}

Key to reading: the type of heating system is used identity factor. It comprises 6 groups: individual boiler, district heating, collective boiler, mixed heating system, heating individual electric convectors, other including renewable energy. 


\section{References}

Ademe, 2005. Stratégie utilisation rationnelle de l'énergie : Chapitre 2 les bâtiments. www2.ademe.fr/servlet/getBin?name=B7491EC9CF8C1E44B4608F700A9B6972114770743 9026.pdf

Agresti, A., 2013. Categorical Data Analysis, 3rd ed. John Wiley \& Sons.

Belleau H., Proulx R., 2010. Equilibre et déséquilibre des comptes amoureux contemporains. Le revenu familial remis en question. Recherches familiales, 7, 85-101.

Belleau H., Proulx R., 2011. Le revenu familial, un concept vague et insidieux : analyse critique et historique des relations économiques familiales. Enfances, Familles, Générations, 15, 78-109.

Boardman, B., 2010. Fixing Fuel Poverty: Challenges and Solutions. Earthscan, London.

Boardman, B., 1991. Fuel Poverty: From Cold Homes to Affordable Warmth. Belhaven Press, London

Browning M., Bourguignon F., Chiappori PA, and Lechêne V., 1994. Income and outcomes: a structural model of intra household allocation. Journal of Political Economy, 102, 1067-1096.

Cazenave MC., Duval J., Eidelman A., Langumier F. and Vicard A., 2011. La redistribution : état des lieux en 2010 et évolution depuis vingt ans. In France portrait social 2011, Insee Références, INSEE.

Devalière, I., Briant P ., Arnault S., 2011. La précarité énergétique : avoir froid ou dépenser trop pour se chauffer. INSEE première $\mathrm{N}^{\circ} 1351$

Devalière, I., 2009. De l'inconfort thermique à la précarité énergétique, profils et pratiques des ménages pauvres. Informations sociales 155, 90-98

Dubois, Ute., 2012. From targeting to implementation: The role of identification of fuel poor households. Energy Policy 49, 107-115

EPEE project: European Fuel Poverty and Energy Efficiency, Intelligent Energy Europe, 2006. Evaluation of fuel poverty in Belgium, Spain, France, Italy and the United Kingdom, WP2

Fahmy, E., Gordon, D., Patsios, D., 2011. Predicting fuel poverty at a small-area level in England. Energy Policy 39, 4370-4377.

Foster, J., Greer, J., Thorbecke, E., 1984. A class of decomposable poverty measures. Econometrica 52(3), 761-765.

Healy, J., 2003. Fuel Poverty and Policy in Ireland and the European Union. Studies in Public Policy 12, Policy Institute at Trinity College

Hills, J., 2012. Getting the Measure of Fuel Poverty. Final Report of the Fuel Poverty Review. Centre for Analysis of Social Exclusion, London School of Economics and Political Science. 
Hills, J., 2011. Fuel Poverty: The problem and its measurement, Interim Report of the Fuel Poverty Review. Centre for the Analysis of Social Exclusion, London School of Economics and Political Science.

IAEA, 2005. Energy Indicators for Sustainable Development: Guidelines and Methodologies. Vienna: International Atomic Energy Agency. Available at: http://wwwpub.iaea.org/MTCD/publications/PDF/Pub1222_web.pdf.

IEA, 2011. Evaluationg the co-benefitrs of low-incomes energy-efficiency programmes. Dublin workshop report 27-28 january 2011. IEA/OCDE. Available on : http://www.iea.org/publications/freepublications/publication/low_income energy_efficiency.p $\underline{\mathrm{df}}$

Li, K., et al., Energy poor or fuel poor: What are the differences? Energy Policy (2013), http://dx.doi.org/ 10.1016/j.enpol.2013.11.012i

INSEE, 2013, Les revenus et le patrimoine des ménages, INSEE Références, Edition 2013.

Lewis, P., 1982. Fuel poverty can be stopped. Bradford: National Right to Fuel Campaign. http://www.iea.org/publications/freepublications/publication/low_income energy_efficien cy-1.pdf

Moore, R., 2012. Definitions of fuel poverty: Implications for policy. Energy Policy 49, 1926

Nussbaumer, P., Bazilian M., Modi V. and Yumkella K.K, 2011. Measuring Energy Poverty: Focusing on What Matters. OPHI working paper no. 42

Pachauri, S., A. Müller, A. Kemmler and D. Spreng, 2004. On measuring energy poverty in Indian households, World Development 32: 2083-2104.

Pachauri, S. and D. Spreng, 2004. Energy use and energy access in relation to poverty. Economic and Political Weekly 39: 17-23.

Pachauri, S. and D. Spreng, 2011. Measuring and monitoring energy poverty. Energy Policy 39: 7497-7504.

Palmer, G., MacInnes, T., Kenway, P., 2008. Cold and Poor: An analysis of the link between fuel poverty and low income. Report New Policy Institute

Powers D. and Xie Y., 2000. Statistical Methods for Categorical Data Analysis, 2nd Edition, Emerald Group Publishing Ltd.

Rappel, 2011. Précarité Energétique: Etat des lieux et propositions d'actions. Report available on: http://www.precarite-energie.org/Precarite-energetique-Etat-des.html

Roy D., 2005. Tout ce qui est à moi est à toi ? Terrain, 45, 41-52, 2005

UNDP. 2000. World Energy Assessment. New York: United Nations Development Programme. 
Whyley, C., Callender, C. 1997. Fuel Poverty in Europe: Evidence from the European Household Panel Survey. Policy Studies Institute, London 